KS. JANUSZ GRĘŹLIKOWSKI

Wydział Prawa Kanonicznego

Uniwersytetu Kardynała Stefana Wyszyńskiego w Warszawie

\title{
ODNOWA DUSZPASTERSKO-RELIGIJNA W DIECEZJI WŁOCŁAWSKIEJ W ŚWIETLE UCHWA SYNODALNYCH BISKUPA MACIEJA ŁUBIEŃSKIEGO (1631-1641)
}

Treść: Wstęp. - 1. Osoba biskupa Macieja Łubieńskiego na tle organizacji i uwarunkowań duszpasterskich diecezji kujawsko-pomorskiej w XVII wieku. - 2. Synody biskupa Łubieńskiego narzędziem odnowy i reformy diecezji i jej duszpasterstwa. - 2.1. Synod diecezjalny z 1634 r. - 2.2. Synod odbyty dla archidiakonatu pomorskiego z $1640 \mathrm{r}$. - 2.3. Synod diecezjalny z 1641 r. - 3. Przekaz i nauczanie depozytu wiary. - 4. Sprawowanie i przyjmowanie sakramentów. - 5. Dyscyplina i karność duchowieństwa. -6 . Regulacje w sprawach majątkowo-administracyjnych i sądowych. - Zakończenie.

\section{Wstęp}

Niedawne jubileuszowe obchody 1050 rocznicy chrztu Polski stwarzają wyjątkową okazję, aby kościelna myśl prawnicza wracała do źródeł i zastanawiała się nad rolą i miejscem ustawodawstwa kościelnego - powszechnego i partykularnego, które w dużej mierze miało i ma wpływ na życie i kształt Kościoła. Szczególnym rodzajem tego ustawodawstwa jest działalność synodalna Kościoła zakorzeniona w samej jego naturze, według której Kościół rozwijał się i odnawiał od swoich początków, poprzez całe wieki, aż do dnia dzisiejszego. Odnosi się to również do działalności synodalnej Kościoła w Polsce na przestrzeni wieków i w dzisiejszych czasach. Działalność synodalna 
miała i ma fundamentalne znaczenie dla kształtowania się prawa partykularnego oraz rozwoju życia kościelnego w Polsce. Stąd w badaniach nad historią prawa kanonicznego w Polsce często sięgamy do działalności ustawodawczej poszczególnych biskupów, ich ustawodawstwa synodalnego, które miało znaczący wpływ na życie i działalność Kościoła w Polsce. Ustawodawstwo to, jakże bogate i twórcze, kształtowało postawy religijno-moralne kapłanów, jak i wiernych, stanowiło dyspozycje co do przekazywania i nauczania wiary, wydawało normy co do sprawowania i przyjmowania sakramentów świętych, kultu Bożego i prowadzenia duszpasterstwa, dyscypliny i karności duchowieństwa, jak też spraw związanych ze sprawami majątkowymi, administracyjnymi oraz sądowymi. Jednocześnie ustawodawstwo to, szczególnie to po Soborze Trydenckim (1545-1563) i po Soborze Watykańskim II (1962-1965), poprzez wzmożoną i ożywioną działalność, przyczyniało się do odnowy i reformy Kościoła, co też zostało zauważone przez prawodawcę kościelnego w regulacjach KPK z 1983 r. $^{1}$

Od wysiłków ustawodawczych biskupów diecezjalnych, zaangażowania i podejmowania działań zmierzających do wprowadzania prawa powszechnego w życie i działalność Kościołów partykularnych zależało dostosowanie prawa diecezjalnego do nowych zasad. Odnosiło się to szczególnie do reformistycznych postanowień trydenckich, które wymagały wdrożenia w życie poszczególnych Kościołów partykularnych. Proces przyswajania osiągnięć Tridentinum zależał w pierwszym rzędzie od osoby stojącego na czele diecezji. Tak też było w pierwszej połowie wieku XVII w diecezji włocławskiej, wtedy nazywanej kujawsko-pomorską ${ }^{2}$ kiedy to na czele diecezji stał

\footnotetext{
${ }^{1}$ Por. kan. 439-446 i 460-468 KPK.

${ }^{2}$ Nazywano ją od początku wieku XII diecezją kujawską. Jednak na synodzie prowincjalnym odbytym w Piotrkowie w 1551 r. nakazano biskupom tytułować się biskup włocławski i Pomorza i odtąd, do początków XIX stulecia, w aktach łacińskich używali oni tytułu episcopus Vladislaviensis et Pomeraniae, a diecezja nosiła nazwę Vladislaviensis et Pomeraniae. W języku polskim jednak nie używano nazwy diecezja włocławsko-pomorska, czy włocławska i pomorska, albo biskup włocławski i pomorski, ale diecezja kujawsko-pomorska lub poprawniej kujawska i pomorska
} 
biskup Maciej Łubieński (1631-1641), późniejszy metropolita gnieźnieński i prymas Polski (1641-1652)3. Można go śmiało zaliczyć do nowej generacji biskupów polskich XVII wieku, którzy mieli znaczący wpływ na kształt reform trydenckich w Kościele polskim, a który jak to ocenił w łacińskiej biografii z 1752 r. Florian Bujdecki - był bardziej człowiekiem Kościoła niż politykiem (magis ecclesiasticus quam politicus $)^{4}$. Jego wkład $\mathrm{w}$ dzieło recepcji uchwał trydenckich w Kościele włocławskim i polskim był ważny i znaczący. Jako biskup kujawsko-pomorski, a później arcybiskup gnieźnieński i prymas, wielokrotnie sięgał do wypróbowanego narzędzia reformy i odnowy, jakim było ustawodawstwo synodalne. Ta właśnie płaszczyzna jego aktywności biskupiej zdecydowanie dominuje nad innymi sposobami kształtowania postaw religijno-moralnych zarówno duchowieństwa, jak i wiernych świeckich. Stąd warto przybliżyć w szczegółowym opracowaniu odnowę duszpasterską diecezji włocławskiej w świetle uchwał odbytych przez niego synodów.

Biskup Łubieński jako biskup kujawsko-pomorski (włocławski), mimo trudnej sytuacji politycznej kraju, odbył trzy synody: dwa diecezjalne w 1634 i 1641 r. oraz synod dla archidiakonatu pomorskiego w $1640 \mathrm{r}$. Ich uchwały stały się nie tylko okazją do przeprowadzenia odnowy duszpasterskiej Kościoła włocławskiego, ale także przyczyniły się do pogłębienia znajomości i szacunku dla prawa oraz stały się skutecznym instrumentem do zachowania jedności i karności kościelnej w diecezji, jak też wprowadzania reformy trydenckiej. Uchwalone na wspomnianych synodach zarządzenia i dyspozycje zasługują na zauważenie i szczegółowe przybliżenie, gdyż podjęte na

oraz biskup kujawski i pomorski. Zob. A. TomczAк, Kancelaria biskupów włocławskich w okresie wpisów (XV-XVIII w.), Roczniki Towarzystwa Naukowego w Toruniu 69(1964) z. 3, s. 17; S. Librowski, Wizytacje diecezji włocławskiej, Archiwa, Biblioteki i Muzea Kościelne 8(1964) cz. I, t. 1, z. 1, s. 29; Por. J. GręźLIKowski, Recepcja reformy trydenckiej $w$ diecezji włocławskiej $w$ świetle ustawodawstwa synodalnego, Włocławek 2000, s. 108-109.

${ }^{3}$ M. Kosman, Między ołtarzem a tronem. Poczet prymasów Polski, Poznań 2000, s. $159-161$.

4 Tamże, s. 161. 
nich uregulowania służyły odnowie duszpasterskiej diecezji włocławskiej przez ponad trzy wieki, gdyż po roku 1641 ustała działalność synodalna w diecezji na ponad trzy wieki, a wznowiły ją dopiero dwa synody odbyte po Soborze Watykańskim $\mathrm{II}^{5}$.

\section{Osoba biskupa Macieja Łubieńskiego na tle organizacji i uwarunkowań duszpasterskich diecezji kujawsko-pomorskiej w XVII wieku}

Maciej Łubieński pochodzący ze starodawnego rodu Pomianów, urodził się 2 lutego 1572 r. w Łubnej, niedaleko Sieradza jako syn Bogusława, kasztelana sandomierskiego i Barbary Zapolskiej. Miał dwie siostry i czterech braci. Trzech z braci było kapłanami: Wojciech proboszcz pułtuski, kanonik gnieźnieński i krakowski, Marcin jezuita, Stanisław - biskup łucki (1624-1627) i płocki (1627-1640). Po spędzeniu młodości w domu rodzinnym i zdobyciu początkowych nauk, podjął naukę w szkołach jezuickich w Sieradzu i Kaliszu. Następnie studiował w wyższej szkole jezuickiej w Poznaniu, a potem prawo na Uniwersytecie Jagiellońskim w Krakowie. Protegowany przez swego wuja Macieja Pstrokońskiego, podjął pracę w kancelarii królewskiej, w której król powierzył mu uporządkowanie archiwum królewskiego. Po kilku latach pracy Pstrokoński wysłał go do Włoch i Niemiec na wyższe studia z zakresu teologii i prawa kanonicznego oraz świeckiego ${ }^{6}$. Po powrocie do kraju i przyjęciu święceń niższych otrzymał w roku 1600 nominację na kanonię poznańską, a niebawem gnieźnieńską. Kiedy jego wujo Maciej Pstrokoński został biskupem przemyskim zabrał swego wychowanka do tejże diecezji

\footnotetext{
${ }^{5}$ Zob. J. GręźLIKowski, Ustawodawstwo synodalne diecezji włocławskiej - stan badań oraz postulaty badawcze, [w:] Semel Deo dedicatum non est ad usum humanos ulterius transferendum. Księga pamiątkowa dedykowana ks. prof. dr. hab. Julianowi Kałowskiemu z okazji siedemdziesiątej rocznicy urodzin (red. J. Wroceński, B. Szewczul, A. Orczykowski), Warszawa 2004, s. 615-637; S. Librowski, Sprawa rzekomych synodów diecezji włocławskiej po 1641 roku, Archiwa Biblioteki i Muzea Kościelne 2(1961) z. 1-2, s. 345-352.

${ }^{6} \mathrm{~J}$. KoRYtкоwsкi, Arcybiskupi Gnieźnieńscy, prymasowie i metropolici polscy od roku 1000 aż do końca 1821 t., t. IV, Poznań 1891, s. 1-6.
} 
wtajemniczając go w pracę duszpasterską i administrowanie diecezją. W 1602 r. Łubieński przyjął święcenia kapłańskie. Na dworze Zygmunta III piastował godność osobistego sekretarza i rejenta kancelarii. Po czym został prepozytem w Łęczycy. Po śmierci biskupa Pstrokońskiego, który wcześniej z Przemyśla przeniósł się do Włocławka, gdzie był biskupem w latach 1608-16097, Łubieński został powołany przez ówczesnego biskupa włocławskiego Wawrzyńca Gembickiego (1610-1616) do Włocławka, gdzie załatwiał dla biskupa Gembickiego i diecezji ważne sprawy kościelne i polityczne, w tym przyczynił się do ustania od dawna toczącego się sporu o dziesięciny pomiędzy stanem duchownym a rycerskim. W 1610 r. otrzymał godność kanonika krakowskiego, a następnie został wyniesiony do godności proboszcza Kanoników Regularnych Grobu Chrystusowego w Miechowie. W 1618 złożył śluby zakonne i zrzekł się wszystkich swoich dotychczasowych godności. Zostawszy przełożonym Bożogrobowców pracował gorliwie nad podniesieniem ducha zakonnego. Opracował nowe przepisy i ustawy dla zgromadzenia, które w roku 1626 zostały zatwierdzone przez papieża Urbana VIII i wydane drukiem pt. Constitutiones capitulorum generaliom miechoviensium ordinis canonicorum regularium ${ }^{8}$.

Łubieński w roku 1620 został mianowany biskupem chełmskim. Po pięciu latach gorliwego pasterzowania, wizytowania diecezji, odbycia synodu, został przeniesiony na stolicę poznańską. Zrzekł się probostwa w Miechowie i podjął gorliwie obowiązki biskupa poznańskiego. W roku 1631 został przeniesiony na biskupstwo włocławskie. Tutaj gorliwie wizytował diecezję, zwołał - jak wspomniano - trzy synody w: 1634, 1640 i 1641 r., odrestaurował katedrę włocławską, wzniósł w niej piękny marmurowy ołtarz i ofiarował do niego cztery obrazy pędzla Bartłomieja Strobela, sprawił dwa dzwony oraz złotą monstrancję. Do statutów synodalnych załączył instrukcję w sprawie ujednolicenia wszelkich obrzędów kościelnych, szczególnie udzielania

\footnotetext{
${ }^{7}$ Diecezja włocławska 2000, Włocławek 2001, s. 51.

${ }^{8}$ J. Korytкowski, Arcybiskupi Gnieźnieńscy..., dz. cyt., s. 6-7; Zob. Z. CHeŁmiński, Podręczna Encyklopedia Kościelna, t. XXV, Warszawa 1911, s. 110-111.
} 
sakramentów. W 1639 r. polecił wydrukować rytuał dla diecezji celem ujednolicenia sprawowania sakramentów i kultu Bożego. Jednocześnie pełnił obowiązki polityczne jako senator, szczególnie aktywnie czynił to po śmierci króla Zygmunta III w roku $1632^{9}$.

18 czerwca 1641 r. zaskakuje go wieść o wyborze dokonanym przez króla Władysława IV na arcybiskupa gnieźnieńskiego, jako najbardziej zasłużonego z biskupów polskich. Miał wtedy 70 lat. Po zatwierdzeniu przez papieża Urbana VIII, jako arcybiskup gnieźnieński wizy tował metropolię, w 1642 r. odbył w Uniejowie synod diecezjalny, a w roku 1643 przeprowadził synod prowincjalny. Z jego inicjatywy odbyło się w Toruniu Colloquium charitativum z protestantami. Dokonał odbudowy spalonej w 1613 r. katedry gnieźnieńskiej i przyczynił się do odbudowy licznych kościołów w archidiecezji. Był na pogrzebie Zygmunta III i Władysława IV oraz na sejmie elekcyjnym Jana Kazimierza, którego 17 stycznia 1649 r. koronował. Od tej chwili odsunął się od życia politycznego i poświęcił się pasterzowaniu. Zmęczony pracą i wiekiem zmarł 28 sierpnia 1652 r. w Łowiczu. Pochowany został w Gnieźnie ${ }^{10}$.

W okresie rządów Kościołem włocławskim przez biskupa Łubieńskiego, a więc w XVII wieku, diecezja wtedy zwana kujawsko-pomorską, rozciągała się długim pasem wzdłuż lewego (zachodniego) brzegu Wisły, w nielicznych miejscach przechodząc na jej brzeg wschodni; zaczynając się na południu od Lubienia, Przedcza i Brdowa, rozciągała się w stronę północy poprzez Włocławek, Kruszwicę, Inowrocław, Bydgoszcz, Pelplin, aż do samych brzegów Bałtyku, do Gdańska, Pucka i Łeby. Obejmowała więc całe Kujawy, wschodnie Pomorze, zwane Pomorzem Gdańskim z ziemią lęborską i bytowską ${ }^{11}$.

\footnotetext{
${ }^{9}$ J. Korytкоwsкi, Arcybiskupi Gnieźnieńscy..., dz. cyt., s. 10-16.

${ }^{10}$ Por. Tamże, s. 17-46; E. JARRA, Twórczość prawna duchowieństwa polskiego, [w:] Sacrum Poloniae Millennium, t. I, Rzym 1954, s. 338; S. CHodyński, Łubieński Maciej, [w:] Encyklopedia Kościelna Nowodworskiego, t. XII, Warszawa 1879, s. 592-601.

${ }^{11}$ B. Kumor, Granice metropolii i diecezji polskich (968-1939), Archiwa Biblioteki i Muzea Kościelne 19(1969) s. 298-299; I. SubER A, Terytorium diecezji włocławskiej i pomorskiej, Warszawa 1962, s. 28-31.
} 
Obszar diecezji podzielony był na trzy archidiakonaty: włocławski, kruszwicki i pomorski ${ }^{12}$. Posiadała oficjalaty: generalny włocławski, zwany też kujawskim, okręgowy gdański, który stopniowo przekształcił się w generalny, nazywany też pomorskim i okręgowy bydgoski $i^{13}$. Za czasów biskupa Łubieńskiego diecezja podzielona była na 20 dekanatów. W archidiakonacie włocławskim było sześć dekanatów: brzeski, kowalski, radziejowski, lubotyński, bobrownicki i służewski; w kruszwickim cztery: kruszwicki, inowrocławski, raciążski i bydgoski, a w pomorskim dziesięć: gdański, mirachowski czyli kościerzyński, pucki, zaborski czyli podlaski albo starogardzki, Wyspy Mniejszej (nazywany zblewskim, a potem giemlickim), tczewski, świecki, nowski, lęborski i gniewski ${ }^{14}$. Dekanat bobrownicki biskup Łubieński utworzył w miejsce nieszawskiego, co było wynikiem pozyskania w 1634 r. z diecezji płockiej czterech nowych zawiślańskich parafii: Ciechocina, Dobrzejewic, Nowogrodu i Złotoryi, które weszły w skład tego nowo utworzonego dekanatu ${ }^{15}$.

Obok archidiakonatów, oficjalatów i dekanatów ważną strukturą w organizacji diecezji były parafie. To one były podstawową formą zorganizowanego życia religijnego, gdzie z kościołem parafialnym wierni byli związani silnymi więzami przymusu parafialnego ${ }^{16}$. Potrzeby religijne chrześcijanina tamtego okresu określone były jako

${ }^{12}$ S. Librowski, Wizytacje diecezji włocławskiej..., dz. cyt., s. 65-66.

${ }^{13}$ P. Hemperek, Oficjalaty okręgowe w Polsce, Roczniki Teologiczno-Kanoniczne 18(1971) z.5, s. 52-55; Por. J. GRĘźLIKOWski, Recepcja reformy trydenckiej..., dz. cyt., s. 114-116.

14 Tamże, s. 117.

${ }^{15} \mathrm{Na}$ mocy ugody między biskupami: braćmi Łubieńskimi: Maciejem - kujawsko-pomorskim i Stanisławem - płockim, parafie Ciechocin, Nowogród i Dobrzejewice z filią w Złotorii, położone w dobrach stołowych biskupów włocławskich, zostały włączone do diecezji włocławskiej. Zmianę tę zatwierdził papież Urban VIII. Zob. Rocznik Diecezji Włocławskiej 2007, Włocławek 2007, s. 30; Por. Acta seu Decreta et Statuta synodalia Wladislaviensis Dioecesis MDCXXXIV, die XVI Maii, et sequentibus sancita, Z. CHodý́sKI, Statuta synodalia dioecesis Wladislaviensis et Pomeraniae, Varsaviae 1890, s. 213; S. Librowski, Synody diecezji włocławskiej, Kronika Diecezji Włocławskiej 50(1967) s. 90.

${ }^{16}$ J. Rutкowski, Historia gospodarcza Polski (do 1864 r.), Warszawa 1953, s. 130. 
przestrzeganie zbioru nakazów, zaleceń, praktyk religijnych oraz pogoń za dobrymi uczynkami. Nie brano pod uwagę wewnętrznej postawy chrześcijanina, co podkreśliła reforma trydencka, zwracając uwagę na głoszenie prawd wiary, nauczanie i rozwijanie wśród wiernych intensywniejszego niż dotąd życia sakramentalnego. W pierwszej połowie XVII wieku na Kujawach było ponad 130 kościołów parafialnych ${ }^{17}$. W części pomorskiej diecezji znajdowało się około 150 kościołów parafialnych. Z ogólnej sumy ponad 280 parafii prawie połowa kościołów znajdowała się we władaniu innowierców ${ }^{18}$. Sytuacja zatem nie była optymistyczna, a rozwój protestantyzmu w diecezji nie przebiegał spokojnie, bowiem innowiercy, szczególnie w części pomorskiej diecezji przejmowali kościoły i dominowali swoimi reformatorskimi poglądami i zachowaniami ${ }^{19}$. Powyższa sytuacja niejako wymuszała na biskupie Łubieńskim konkretne działania ustawodawcze i duszpasterskie, w tym szczególnie mające na celu odrodzenie życia religijnego poprzez ożywienie życia sakramentalnego oraz dyscyplinę i karność duchowieństwa.

W omawianym okresie życia i działalności Kościoła duchowieństwo diecezjalne i zakonne nie zawsze spełniało wymogi stawiane tej grupie kościelno-społecznej. Było słabo wykształcone i nie przygotowane duchowo i religijnie do pracy duszpasterskiej; samo ulegało błędom i promowało postawę agnostycyzmu i etycznego relatywizmu, co więcej nie było przygotowane do właściwego kształtowania życia religijnego wiernych. Następował ogromny rozdźwięk pomiędzy teorią i praktyką, między zasadami i prawdami Ewangelii a hedonistycznym, świeckim życiem duchowieństwa i wiernych świeckich.

${ }^{17}$ J. KŁoczowski, Uwagi wstępne. Chrześcijaństwo polskie XVI-XVIII wieku, [w:] Kościół w Polsce, pr. zb. pod red. J. Kłoczowskiego, t. II, Kraków 1970, s. 39-53; Zob. S. Chodý́ski, Włocławska diecezja, [w:] Encyklopedia Nowodworskiego, t. XXXII, Płock 1913, s. 60.

${ }^{18}$ Zob. S. CHodýski, Monumenta historica dieceseos wladislaviensis, t. I, Wladislaviae 1881, s. 24.

${ }^{19}$ J. KŁoczowski, Uwagi wstępne. Chrześcijaństwo polskie XVI-XVIII wieku..., dz. cyt., s. 45-51. 
Również poważny kryzys przechodziły zakony i klasztory ${ }^{20}$. To wszystko powodowało, że reformacja związana początkowo z ruchem politycznym i społecznym, nabierała charakteru religijnego. Silne wpływy reformacyjno-protestanckie uwidoczniły się na Pomorzu, z Gdańskiem na czele. Na rozwój protestantyzmu na terenach diecezji włocławskiej tamtego czasu duży wpływ miało szkolnictwo, gdzie dobrze zorganizowane gimnazja luterańskie funkcjonowały w Gdańsku i Toruniu i kształciły młodych w duchu reformacji ${ }^{21}$.

W kujawskiej części diecezji luteranizm był mniej popularny niż na Pomorzu, ze względu na swoje niemieckie pochodzenie, jednak mimo to także wielu było jego zwolenników, szczególnie w Radziejowie, gdzie na skutek działalności starosty radziejowskiego Rafała Leszczyńskiego zostały zamknięte kościoły w Płowcach, Bytoniu, a ziemie plebańskie włączono do dworskich. Także w Nieszawie, Lubrańcu, Konecku powstawały liczne konflikty, a nawet gwałtowne starcia, których celem było dyskredytowanie Kościoła katolickiego. $\mathrm{Na}$ silny wpływ reformacji na Kujawach miało znaczenie sąsiedztwo miast pruskich, a szczególnie Torunia, ze szkołą miejską, późniejszym gimnazjum $^{22}$.

Poważnym utrudnieniem pracy duszpasterskiej w ówczesnej diecezji włocławskiej był brak odpowiedniego wykształcenia wśród duchowieństwa oraz niski jego poziom moralny. Ograniczenia intelektualne i moralne duchowieństwa były tak daleko niestosowne, że biskup Łubieński w synodzie z $1641 \mathrm{r}$. zdecydowanie przypominał o obowiązkach stanu duchownego piętnując wszelkie nadużycia w życiu i postępowaniu kapłanów ${ }^{23}$. W innym miejscu synod zobowiązywał

\footnotetext{
${ }^{20}$ A. WeIss, Czasy nowożytne. Kryzys w przededniu reformacji, [w:] Być chrześcijaninem dziś, red. M. Rusecki, Lublin 1992, s. 538-540.

${ }^{21}$ P. SKWARCZYŃsKI, Szkice $z$ dziejów reformacji $w$ Europie środkowo-wschodniej, Londyn 1967, s. 19.

${ }^{22}$ J. GręźLIKowski, Recepcja reformy trydenckiej..., dz. cyt., s. 129.

${ }^{23}$ Synodus Dioecesana sub /.../ Mathia Łubieński /.../ episcopo Wladislaviensi et Pomeraniae, Wladislaviae, Anno Domini Millesimo Sexcentesimo Quadragesimo Primo, Die Nona Mensis Junii, celebranta, Z. Chodý́ski, Statuta synodalia..., dz. cyt., s. 237.
} 
duchowieństwo do życia zgodnego z duchem Kościoła, do przestrzegania przepisów kościelnych i wypełniania swoich obowiązków odnośnie do sprawowania sakramentów. Biskup ubolewał, że duchowieństwo nie zna norm prawa powszechnego i diecezjalnego ${ }^{24}$. Te urzędowe napomnienia dają wyraźny, a zarazem smutny obraz życia ówczesnego duchowieństwa. Tym samym duszpasterstwo u podstaw którego leży przykład życia, moralność i świętość życia duszpasterzy, pozbawione było mocy skutecznego oddziaływania ${ }^{25}$. Należy zauważyć, że miało to miejsce już po przyjęciu uchwał Tridentinum przez sejm w Parczewie w 1564 r. i synod prowincjonalny w Piotrkowie z $1577 \mathrm{r}^{26}$ i po wielu synodach włocławskich odbytych przez poprzedników biskupa Łubieńskiego.

Ważną i znaczącą rolę w prowadzeniu duszpasterstwa i odnowie życia religijnego w XVII wieku na terenie diecezji miały zakony, które starały się rozwijać działalność odpowiadającą zmienionym warunkom celem utrzymania przy Kościele wiernych i sprowadzenia do niego odłączonych. Za główne środki do tego uważano wtedy: wychowanie młodzieży, prowadzenie misji ludowych i akcji charytatywnej ${ }^{27}$. W pierwszej połowie XVII wieku w diecezji kujawskiej i pomorskiej swoje domy zakonne posiadało sześć zgromadzeń męskich w czternastu miejscowościach (Dominikanie - Brześć, Tczew, Gdańsk; Franciszkanie - Nieszawa, Inowrocław, Bydgoszcz, Radziejów, Nowe; Cystersi - Oliwa, Pelplin, Koronowo; Augustianie - Lubraniec; Kartuzi - Kartuzy i Karmelici - Gdańsk) i trzy żeńskie, w czterech miastach (Norbertanki - Żukowo, Strzelno; Benedyktynki - Żarnowiec, Brygidki - Gdańsk) ${ }^{28}$. Znajdujące się w tym okresie na terenie diecezji zgromadzenia zakonne nie zawsze przyczyniały się swoją

\footnotetext{
${ }^{24}$ Tamże, s. 239-240.

${ }^{25}$ M.T. ZaHAJKIEWICZ, Średniowieczne ustawodawstwo synodalne Kościoła polskiego źródłem badań dziejów duszpasterstwa, Studia Theologica Varsaviensia 27(1989) nr 1, s. 137-138.

${ }^{26}$ A. Pawiński, Synod piotrkowski w roku 1577, [w:] Źródła dziejowe, t. IV, Warszawa 1877, s. I-XXXVII.

${ }^{27}$ J. GręźLIKOWSKI, Recepcja reformy trydenckiej..., dz. cyt., s. 133.

${ }^{28}$ I. Subera, Terytorium diecezji włocławskiej i pomorskiej..., dz. cyt., s. 65-67.
} 
działalnością do ożywienia duszpasterstwa, często opaci lekceważyli jurysdykcję biskupią i ustanawiane przez biskupów zarządzenia, doprowadzali do ruiny budynki zakonne, prowadzili gorszące życie, a nawet popierali innowierców. ${ }^{29}$ Stąd można powiedzieć, że obraz życia zakonników niewiele różnił się od duchowieństwa diecezjalnego i również wymagał głębokich reform i podjęcia zdecydowanych działań uzdrawiających.

Widocznych zatem było w diecezji włocławskiej połowie XVII wieku wiele zaniedbań i nieprawidłowości na wszystkich płaszczyznach, które winny być objęte ewangelizacją i duszpasterstwem. Taki stan rzeczy w obliczu rozwijającej się reformacji wymagał głębokiej naprawy i natychmiastowej promulgacji nowych wymogów działalności duszpasterskiej poprzez uregulowania ustawodawcze podjęte na synodach. Odnosiło się to przede wszystkim do życia sakramentalnego, religijnego oraz dyscypliny i karności kościelnej, a także ożywienia duszpasterstwa.

\section{Synody biskupa Macieja Łubieńskiego narzędziem reformy i odnowy diecezji i jej duszpasterstwa}

Uchwały synodalne biskupa Macieja Łubieńskiego, te diecezjalne i dla archidiakonatu pomorskiego, były ostatnim, bardzo ważnym i doniosłym akcentem reformy trydenckiej w diecezji kujawsko-pomorskiej, czyli włocławskiej. Obejmując, jako pięćdziesiąty piąty biskup włocławski, bardzo rozległą diecezję w roku 1631 dostrzegał wiele zaniedbań, szczególnie w jej części pomorskiej, gdzie protestantyzm rozprzestrzeniał się od Prus i był bardzo żywy i aktywny. Nadto archidiakonat pomorski odznaczał się sporym spustoszeniem spowodowanym niedawną wojną ze Szwedami. Piętno zniszczenia wycisnęła też wojna pruska, na skutek której wiele kościołów zostało opuszczonych, a wiele zajętych przez innowierców. Nadto wiele kościołów, szczególnie tych które utrzymywane były z dóbr szlacheckich, było bardzo ubogich i często pozbawionych stałych dochodów.

\footnotetext{
29 J. GręźLIKowski, Recepcja reformy trydenckiej..., dz. cyt., s. 166-168; Por. M. MoRAWSKi, Monografia Włocławka, Włocławek 1933, s. 205-206, 222, 231, 241.
} 
Jeszcze w gorszym stanie znajdowały się parafie położone na terenie posiadłości innowierców. $Z$ tego powodu wiele parafii archidiakonatu pomorskiego nie posiadało stałej obsługi duszpasterskiej, co powodowało u wiernych - jak wspomniano wcześniej - indyferentyzm religijny. Pragnąc temu zapobiec opuszczone parafie oddawał w opiekę sąsiednim księżom, a także wystąpił do Stolicy Apostolskiej o pozwolenie na kumulację dwóch lub więcej parafii duchownym archidiakonatu pomorskiego, aby w ten sposób zwiększyć ich niewystarczające uposażenie i rozwiązać problem nieobsadzonych parafii. Stolica Apostolska przychylnie odniosła do prośby biskupa Łubieńskiego i udzieliła indultu papieskiego pozwalającego biskupowi na powierzanie, według swego uznania, proboszczom posiadającym wystarczające beneficja, obsługę parafii opuszczonych, byle tylko nie ucierpiało dobro wiernych ${ }^{30}$.

Zastany stan duszpasterski diecezji, szczególnie w archidiakonacie pomorskim, wymagał od biskupa gorliwości i sprężystego działania. Toteż przepełniony troską o dobro Kościoła, diecezji i wiernych świeckich podejmuje wiele prac i inicjatyw administracyjno - prawnych, materialnych, organizacyjnych i duszpasterskich, w czym wspomagali go biskupi pomocniczy ${ }^{31}$. Najpierw przywraca katedrze dawną jej świetność poprzez renowację dachu, podwyższenie wieży, ufundowanie nowego ołtarza głównego i czterech obrazów pędzla Bartłomieja Strobla, ucznia Rubensa, nowej złotej monstrancji, ożywienie

${ }^{30}$ S. Chodý́ski, Monumenta historica dioeceseos wladislaviensis, t. VIII, Wladislaviae 1892, s. 78; Por. J. GręźLıKowski, Recepcja reformy trydenckiej..., dz. cyt., s. 166-168.

${ }^{31}$ Obejmując diecezję włocławską biskup Łubieński miał do pomocy biskupa pomocniczego Baltazara Miaskowskiego, który przyczynił się, że w rok po objęciu diecezji, biskup Łubieński po zwizytowaniu przez siebie niektórych parafii, mógł przesłać do Stolicy Apostolskiej sprawozdanie ze stanu diecezji. Po jego śmierci, w roku 1635 biskupem pomocniczym włocławskim został wybrany przez Łubieńskiego Krzysztof Charbicki, prepozyt kapituły katedralnej, a po nim Wacław Paprocki. Zob. S. CHody Ński, Biskupi sufragani włocławscy, Włocławek 1906, s. 49-52. 
i ubogacenie kultu Bożego sprawowanego w katedrze ${ }^{32}$. Następnie, po przeprowadzeniu wizytacji kapituły katedralnej, 16 kwietnia $1632 \mathrm{r}$. wydaje dekret reformacyjny kapituły, co było podyktowane troską o sprawowanie kultu Bożego, a także właściwe i zgodne z prawem funkcjonowanie kapituły w diecezji ${ }^{33}$. Po tych konkretnych przedsięwzięciach pasterskich podjął także działalność synodalną. Jako pasterz diecezji włocławskiej - jak wspomniano - odbył trzy synody: diecezjalne w 1634 i 1641 r. oraz cząstkowy dla archidiakonatu pomorskiego w 1640 r., którego akta zaginęły ${ }^{34}$.

\subsection{Synod diecezjalny z $1634 \mathrm{r}$.}

Inicjatywa jego zwołania i odbycia rozpoczęła się dnia 6 lutego 1634 r., kiedy to z kancelarii biskupa Łubieńskiego wyszedł okólnik konwokacyjny, który oznajmił, że „w trzecią ferię po IV niedzieli po Wielkanocy, tj. 16 maja tegoż roku rozpocznie swe obrady w katedrze włocławskiej synod diecezjalny"35. Bezpośrednią przyczyną zwołania synodu - jak zaznaczał biskup - była zapowiedź mającego odbyć się w listopadzie 1634 r. synodu prowincjalnego w Warszawie ${ }^{36}$ oraz chęć zaradzenia potrzebom duszpasterskim diecezji i ugruntowania reformy trydenckiej ${ }^{37}$. Pismo wzywające na synod zobowiązywało

${ }^{32}$ S. Chodyński, Monumenta historica dioeceseos Vladislaviensis..., dz. cyt., t. VIII, s. 5-6; M. Morawski, Monografia Włocławka..., dz. cyt., s. 205-206, 222, 231, 241; S. CHоDý́sкi, Organy, śpiew, muzyka w kościele katedralnym włocławskim, Włocławek 1902, s. 152-154.

${ }^{33}$ S. Librowski, Kapituła katedralna włocławska. Zarys dziejów i organizacji, Warszawa 1949, s. 69; J. FIJAŁEK, Statuty kapituły katedralnej włocławskiej z materiałów przysposobionych przez ks. Stanisława Chodyńskiego, Kraków 1915, s. 239-241.

${ }^{34}$ Z. Chodý́ski, Statuta synodalia..., dz. cyt., s. XXXV-XXXVI.

${ }^{35}$ Wcześniej, bowiem w uroczystość Trzech Króli 1634 r. na posiedzeniu generalnym kapituły włocławskiej biskup konsultował z członkami kapituły odbycie synodu, jego tematykę i termin. Zob. Z. CHodý́ski, Statuta synodalia..., dz. cyt., s. XXXV.

${ }^{36}$ Zob. I. SuberA, Synody prowincjonalne arcybiskupów gnieźnieńskich, Warszawa 1981, s. 134-137.

${ }^{37}$ Indictio Synodi Mathias Łubieński Dei et Apostolicae Sedis Gratia Episcopus Wladislaviensis et Pomerania, Z. CHodý́ski, Statuta synodalia..., dz. cyt., s. 196-197. 
dziekanów, aby przywieźli na obrady wszelkie dane dotyczące stanu kościołów i parafii swego dekanatu, a więc: prawa i przywileje kościołów, inwentarze sprzętu kościelnego, dokumenty święceń, prowizji kanonicznej i dyspens, wykaz wypadków skandalicznych i gorszących w parafii oraz sprawozdania mówiące w jakim stopniu zostały wykonane przepisy dekretu wizytacyjnego danej parafii ${ }^{38}$. Obrady synodalne rozpoczęły się 16 maja w katedrze włocławskiej i trwały trzy dni.

Biskup Łubieński przedstawił zebranym tematykę obrad, która obejmowała sprawy: duchowieństwa, przestrzegania przepisów dotyczących sprawowania kultu Bożego, udzielania sakramentów, spełniania posług religijnych i duszpasterskich, karności i dyscypliny duchowieństwa ich życia i obyczajów, nauczania i głoszenia kazań, a także kwestii utworzenia dekanatu bobrownickiego z pozyskanych w 1633 r. z diecezji płockiej czterech parafii zawiślańskich: Ciechocin, Nowogród, Dobrzejewice i Złotoria ${ }^{39}$ oraz erygowania drugiego seminarium duchownego dla części pomorskiej diecezji ${ }^{40}$. Uchwały synodalne - zdaniem Łubieńskiego - miały przyczynić się do przeprowadzenia głębszej, jakże potrzebnej reformy Kościoła diecezjalnego - duchowieństwa i wiernych ${ }^{41}$.

Owocem obrad synodu były obszerne uchwały, które zostały ujęte w dwadzieścia dwa artykuły rozwijające przedstawione przez biskupa propozycje ${ }^{42}$. Obok uchwał synodalnych ściśle ustawodawczych,

${ }^{38}$ Tamże, s. 197.

${ }^{39}$ Zob. Rocznik Diecezji Włocławskiej..., dz. cyt., s. 30.

${ }^{40}$ Acta seu Decreta et Statuta synodalia Wladislaviensis Dioecesis MDCXXXIV, die XVI Mai, et sequentibus sancita, Z. CHodý́ski, Statuta synodalna..., dz. cyt., s. 200-219.

${ }^{41}$ Tamże, 198-199; Por. Praefatio synodo per [...] Episcopum Wladislaviensem et Pomeraniae praemissa, Z. Chodý́ski, Statuta synodalia..., dz. cyt., s. 198.

${ }^{42} \mathrm{O}$ propozycji artykułów przedstawionych przez biskupa na synod dowiadujemy się z posiedzenia kapituły włocławskiej, która je aprobowała, dołączając do rozpatrzenia na synodzie aktualne sprawy duszpasterskie. Zob. Archiwum Diecezji Włocławskiej, Akta Kapituły Katedralnej, N. 9 (223) k. 289 i 310; Por. Sermo in conclusione synodi ab Illustrissimo Domino Episcopo habitus, Z. CHODYŃski, Statuta synodalna..., s. 220-221; Acta seu Decreta et Statuta synodalia Wladislaviensis 
duszpasterskich i administracyjnych, utworzono z parafii zawiślańskich, pomnożonych pozyskaniem $\mathrm{z}$ diecezji płockiej czterech nowych parafii, dekanat bobrownicki, erygowano drugie seminarium dla części pomorskiej diecezji w Szotland. Materiał ustawodawczy jaki podjął synod został umiejętnie podparty dekretami Soboru Trydenckiego, dekretami Stolicy Apostolskiej, a szczególnie bullą papieską Coenae Domini zamieszczoną w aktach synodu in extenso, statutami synodów prowincjalnych, Pismem Świętym oraz listem pasterskim kardynała Maciejowskiego ${ }^{43}$.

Akta synodu polecił biskup Łubieński wydrukować. Ukazały się one drukiem w tym samym roku w drukarni królewskiej, u wdowy Jana Rossowskiego w Warszawie pod tytułem: Synodus dioecesana Vladislaviensis. Ab Ill-mo et R-mo Domino, D. Mathia Łubieński, Dei et Ap. Sedis gratia Episcopo Vlad. Et Pomeraniae in sue ecclesia cathedrali, Anno Domini Millesimo Sexcentesimo Trigesimo Quarto. Die XVI Maii cum universo Clero Dioecesis eiusdem celebrata. Varsoviae apud viduam Joannis Rossowski, S. R. M. Typ. Anno Domini $1634^{44}$. Oprócz uchwał synodalnych w tomie tym umieszczono pismo biskupa zwołujące synod, mowę biskupa na rozpoczęcie i zakończenie synodu. Do wydania statutów polecił prawodawca dołączyć list pasterski kardynała Maciejowskiego i tak wydane dzieło po raz pierwszy wręczył członkom kapituły katedralnej na posiedzeniu generalnym po uroczystości Trzech Króli 1635 r. ${ }^{45}$, a następnie zostało ono rozprowadzone wszystkim kapłanom i zakonom w diecezji ${ }^{46}$.

Powyższe statuty synodalne ponownie zostały wydane w roku 1711 za sprawą biskupa Konstantego Szaniawskiego, który to nakazał je

Dioecesis MDCXXXIV, die XVI Maii, et sequentibus sancita, Z. CHODYŃSKI, Statuta synodalia..., dz. cyt., s. 200-219.

${ }^{43}$ Acta seu Decreta et Statuta synodalia Wladislaviensis Dioecesis MDCXXXIV, die XVI Maii, et sequentibus sancita, Z. CHodyński, Statuta synodalia..., dz. cyt., s. 200-219.

${ }^{44}$ Z. Chodý́ski, Statuta synodalna..., dz. cyt., s. XXXV-XXXVI.

${ }^{45}$ Archiwum Diecezji Włocławskiej, Akta Kapituły Katedralnej, N. 9 (223) k. 310.

${ }^{46}$ Z. Chodý́ski, Statuta synodalna..., dz. cyt., s. XXXVI. 
wydrukować nie zdoławszy odbyć własnego synodu ${ }^{47}$. Po raz trzeci opublikował je Zenon Chodyński w 1890 r. w swoim zbiorze synodów włocławskich ${ }^{48}$.

2.2. Synod odbyty dla archidiakonatu pomorskiego z $1640 \mathrm{r}$.

Drugi synod biskupa Łubieńskiego w diecezji odbył się 23 września 1640 r. w Subkowach pod jego osobistym przewodnictwem. Został zwołany w celu zaradzenia potrzebom duszpasterskim archidiakonatu pomorskiego, o których wspominał synod diecezjalny z $1634 \mathrm{r}^{49}$ i był synodem cząstkowym. Ponieważ duchowieństwo z części pomorskiej diecezji nie mogło w pełni brać udziału na synodzie wcześniejszym i byli na nim obecni tylko dziekani, nie było możliwości omawiania szczegółowych spraw i rozwiązań duszpasterskich tej części diecezji. Odczuwając jednak potrzebę wyjścia naprzeciw trudnościom duszpasterskim i ich uregulowania dla dobra wiernych, a także wsłuchania się w głosy duchowieństwa archidiakonatu pomorskiego, biskup obrady synodalne postanowił odbyć w kościele parafialnym w Subkowach. Chodziło także o umożliwienie duchowieństwu z Pomorza łatwiejszego dostępu do miejsca debaty synodalnej, dotarcie bowiem do Włocławka nastręczało sporo trudności. Nie wiemy jaki był przebieg synodu i jakie były jego uchwały, bowiem nie ukazały się drukiem, ani nie ma ich w rękopisie. Zostało to spowodowane zaniedbaniem sekretarza biskupa, który tych czynności biskupa Łubieńskiego nie spisal ${ }^{50}$.

Jedynym dowodem odbycia tego synodu jest zamieszczona notatka w aktach biskupich ${ }^{51}$ oraz pismo wystawione w Wolborzu dnia

\footnotetext{
${ }^{47}$ Tamże, s. XXXVII.

${ }^{48}$ Acta seu Decreta et Statuta synodalia Wladislaviensis Dioecesis MDCXXXIV, die XVI Mai, et sequentibus sancita, Z. CHodyŃski, Statuta synodalia..., dz. cyt., s. 200-219.

${ }^{49}$ Archiwum Diecezji Włocławskiej, Akta Biskupów Kujawsko-Pomorskich, N. 21(40) k. 79.

${ }^{50}$ Z. ChodyŃski, Statuta synodalna..., dz. cyt., s. XXXV-XXXVI.

${ }^{51}$ Archiwum Diecezji Włocławskiej, Akta Biskupów Kujawsko-Pomorskich, N. 21 (40) k. 791.
} 
27 sierpnia 1640 r. zwołujące synod na 25 września tegoż roku, w którym prawodawca diecezjalny stwierdzał: "ponieważ zbliża się synod prowincjalny, należy odbyć zgodnie z obowiązkiem i gorliwością synod diecezjalny [...] najpierw na terenie Pomorza, celem narady w sprawach majątku kościelnego i duszpasterstwa [...] aby duchowieństwa nie musiało udawać się do Włocławka, co połączone jest z niewygodą i szkodą dla owiec. Przeto prosimy i wzywamy wszystkich będących dyspozytariuszami dóbr kościelnych [...] dziekanów, proboszczów i zarządców dóbr kościelnych [...] pod karą dziesięciu złotych na rzecz szpitala starogardzkiego dla kapłanów, aby przybyli dnia 25 września 1640 r. na synod" 52 .

Celem zwołania tego synodu - jak pisał biskup - było zaradzenie potrzebom uposażenia proboszczów, właściwego zarządzania dobrami kościelnymi oraz rewindykacja kościołów i przywracanie wiary katolickiej ${ }^{53}$. Jak potoczyły się obrady synodalne i jakie podjęto uchwały trudno jest ustalić. Propozycje wysunięte przez prawodawcę synodalnego były ważne i doniosłe i zapewne uchwały synodalne przyczyniły się do zaradzenia potrzebom duszpasterskim archidiakonatu pomorskiego.

\subsection{Synod diecezjalny z $1641 \mathrm{r}$.}

Trzeci synod biskupa Łubieńskiego został zwołany pismem okólnym, na którym brak jest daty, do Włocławka na dzień 9 czerwca $1641 \mathrm{r}$. W mowie inauguracyjnej biskup Łubieński podał motywy, które go skłoniły do zwołania synodu: przygotowanie się diecezji do zapowiedzianego synodu prowincjalnego, przywrócenie naruszonych dóbr kościelnych i troska o kościoły i własność kościelną, podniesienie dyscypliny, moralności i gorliwości duchowieństwa oraz ujednolicenie sprawowania kultu Bożego i udzielania sakramentów. Od obowiązku uczestniczenia w synodzie zostało zwolnione

\footnotetext{
${ }^{52}$ Archiwum Diecezji Włocławskiej, Akta Biskupów Kujawsko-Pomorskich, N. 21 (40) k. 791 i k. 792.

${ }^{53}$ Zob. Z. Chodyński, Statuta synodalna..., dz. cyt., s. XXXVI.
} 
duchowieństwo archidiakonatu pomorskiego, albowiem uczestniczyło ono na synodzie cząstkowym w $1640 \mathrm{r} .{ }^{54}$

W oparciu o analizę treści statutów można ustalić następujące grupy tematyczne, które zostały podjęte przez prawodawcę synodalnego: obrony wiary, beneficja i obowiązki beneficjatów, sakramenty, sprawy kultu Bożego, nauczanie i głoszenie słowa Bożego, miejsca i czasy święte, dyscyplina kleru, urzędy diecezjalne, życie religijno moralne wiernych, rezerwaty, sprawy administracyjne i majątkowe. Erygowano na synodzie dom księży emerytów w Starogardzie Gdańskim i wprowadzono orkiestrę, zwaną wtedy muzyką albo kapelą, do nabożeństw katedralnych ${ }^{55}$.

Statuty synodalne zostały podzielone na trzy rozdziały: De Officiis Divinis rite peragendis et Caeremoniis ad cultum Divinum spectantibus (19 artykułów) $)^{56}$; De conservatione ecclesiarum et iuribus ipsarum $(14 \text { artykułów })^{57}$ oraz De vita et honestate Cleri (13 artykułów) ${ }^{58}$. Tak ujęty i bogaty materiał prawny był próbą prezentacji obowiązującego prawa kościelnego, co więcej, to prawo uszczegóławiał dla realizacji przede wszystkim zadań duszpasterskich w diecezji i potrzeb konkretnych parafii mając na względzie przede wszystkim postanowienia Tridentinum. One były inspiracją dla uchwał synodalnych i kształtowały prawo diecezjalne.

Redakcja i treść statutów synodalnych świadczy o pewnym doświadczeniu redaktora, co sprawiło, że całość uchwał synodalnych jest przejrzysta i czytelna, aczkolwiek nie we wszystkich artykułach. Statuty synodalne nie posiadają żadnego wstępu, lecz rozpoczynają

\footnotetext{
${ }^{54}$ Sermo [...] Mathiae Łubieński [...] Episcopi Wladislaviensi et Pomeraniae, habitus in Synodo Dioecesana Wladislaviensi, Z. CHodý́ski, Statuta synodalia..., dz. cyt., s. 222-223.

${ }^{55}$ Conclusio, Z. Chodyński, Statuta synodalia..., dz. cyt., s. 239.

${ }^{56}$ Zob. Synodus Dioecesana sub [...] Mathia Łubieński [...] episcopo Wladislaviensi et Pomeraniae, Wladislaviae, Anno Domini Millesimo Sexcentesimo Quadragesimo Primo, Die Nona Mensis Junii, celebrate, Z. Chodý́ski, Statura synodalia..., dz. cyt., s. 224-232.

${ }^{57}$ Zob. Tamże, s. 232-236.

${ }^{58}$ Zob. Tamże, s. 236-239.
} 
się od razu od tekstu pierwszego artykułu. Postanowienia synodu na polecenie biskupa Łubieńskiego zostały wydrukowane w roku 1642 w drukarni krakowskiej Franciszka Caesariusa pod tytułem: Synodus dioecesana sub Ill-mo ac R-mo Domino, D. Matthia Łubieński, Dei et Ap. Sedis gratia, Episcopo Vladislaviensi et Pomeraniae, Vladislaviae Anno Domini Millesimo, Sexcentesimo, Quadragesimo Primo, die nona mensis Junij, celebrata, Cracoviae, in officina Typographica Francisci Caesarij, anno Domini $1642^{59}$. Ponowna ich edycja miała miejsce w 1711 r., kiedy to zostały wydane w Warszawie wraz ze statutami z 1634 r. na polecenie biskupa Konstantego Szaniawskiego ${ }^{60}$. Po raz trzeci statuty synodu opublikował w 1890 r. ks. Zenon Chodyński w swoim zbiorze wraz z okólnikiem konwokacyjnym zwołującym synod i mową biskupa na zakończenie synodu ${ }^{61}$.

Synod z 1641 r. był ostatnim synodem włocławskim w Polsce przedrozbiorowej. Przyczyną zaprzestania zwoływania synodów w diecezji od połowy XVII wieku było smutne i trudne położenie kraju, a więc ciągłe wojny a potem rozbiory, ale również - jak to tłumaczy ks. prof. Stanisław Librowski - pewne zaniedbania ze strony późniejszych biskupów włocławskich ${ }^{62}$. Odtąd synody diecezjalne zastępowały, przynajmniej w części, sesje generalne kapituły. Na nich biskupi włocławscy rozstrzygali sprawy odnoszące się do duchowieństwa i wiernych kierując się przede wszystkim ustawodawstwem powszech-

${ }^{59}$ Z. Chodý́ski, Statuta synodalia..., dz. cyt., s. XXXVII. Egzemplarze tego wydania znajdują się w Bibliotece Seminarium Duchownego we Włocławku (sygnatura - XVII. Q. 1436).

${ }^{60}$ Biskup Szaniawski polecił uchwały tych dwóch synodów wydrukować z ich oryginalnymi tytułami w jednej księdze, dodając jedynie na dole karty tytułowej napis: Reimpressa (tzn. prima et secunda Synodus Łubieńskiego) Varsaviae, Typis Coll. Scholarum Piarum, anno Domini 1711. Zob. Z. CHodý́ski, Statuta synodalia..., dz. cyt., s. XXXVII.

${ }^{61}$ Synodus Dioecesana sub [...] Mathia Eubieński [...] episcopo Wladislaviensi et Pomeraniae, Wladislaviae, Anno Millesimo Sexcentesimo Quadragesimo Primo, Die Nona Mensis Juinii, celebranta, Z. Chodý́ski, Statuta synodalia..., dz. cyt., s. 222-239.

${ }^{62}$ S. Librowski, Sprawa rzekomych synodów diecezji włocławskiej po 1641 r..., dz. cyt., s. 346. 
nym, uchwałami dawnych synodów prowincjalnych i diecezjalnych, częstszych w tym czasie rozporządzeń i prawa zwyczajowego ${ }^{63}$.

\section{Przekaz i nauczanie depozytu wiary}

Uchwały synodów biskupa Łubieńskiego zwracały uwagę na całą gamę spraw i zagadnień związanych z życiem i posłannictwem Kościoła, przede wszystkim zaś regulowały bardzo ważną jak na ówczesne czasy dziedzinę życia Kościoła, jaką była obrona i troska o nieskazitelność wiary katolickiej, a także o nauczanie kaznodziejskie, katechizację w kościele i nauczanie religijne w szkole parafialnej, co miało bezpośredni związek z odnową duszpasterską diecezji. Poszczególne statuty synodalne jasno i stanowczo broniły depozytu wiary katolickiej pod sankcją kar kanonicznych oraz regulowały sprawy związane z przepowiadaniem i nauczaniem.

W statutach pierwszego synodu Łubieńskiego znajdujemy dyspozycję nakazującą duchownym publiczne złożenie wyznania wiary kiedy obejmowali beneficja duszpasterskie i nieduszpasterskie, kierownictwo w szkołach, godności kanonickie oraz urzędy kaznodziejskie, szczególnie w części pomorskiej diecezji ${ }^{64}$. Zdaniem biskupa „wiara jest fundamentem religii, bez której ani Kościół nie ma racji swego istnienia, ani ludzie nie mogą podobać się Bogu"65. Stąd w sposób szczególny akcentował nieskazitelność wiary u osób duchownych i zobowiązywał ich do złożenia publicznego wyznania wiary.

Ważnym zagadnieniem w kwestii obrony wiary była sprawa innowierców, nazywanych wówczas heretykami, bądź dysydentami. Relacja do innowierców była przedmiotem dyskusji na obu synodach diecezjalnych, które dużą rolę przywiązywały do sposobu traktowania mieszkających na terenie poszczególnych parafii innowierców.

\footnotetext{
${ }^{63}$ S. Librowski, Konferencje biskupów XVIII wieku jako instytucja zastępująca synody prowincjonalne, Archiwa Biblioteki i Muzea Kościelne 47(1983) s. 251.

${ }^{64}$ Acta seu Decreta et Statuta synodalia Wladislaviensis Dioecesis MDCXXXIV, die XVI Maii, et sequentibus sancita, Z. CHODyŃski, Statuta synodalia..., dz. cyt., s. 199.

${ }^{65}$ Tamże, s. 200.
} 
Biskup Łubieński nakazywał proboszczom, aby najpierw w stosunku do innowierców zamieszkujących na terenie ich parafii podchodzili z dużą dozą łagodności i z roztropnością. Postulował, aby proboszczowie gromadzili ich nawet w domach prywatnych i wykazując im błędy, przedstawiali zdrową naukę wiary. Winni ich otoczyć troską duszpasterską, aby zachęcić do przejścia na wiarę katolicką. Synod postulował, aby duchowni, którzy nie byli przygotowani doktrynalnie do takiej formy duszpasterstwa, sami prosili biskupa o skierowanie do tej pracy innego proboszcza, tj. lepiej przygotowanego do pracy $\mathrm{z}$ innowiercami. W podobny sposób zalecano traktowanie tych parafian, którzy byli notorycznymi odstępcami od wiary. Dopiero gdy ojcowskie upomnienie nie skutkowało, należało zgłosić sprawę do urzędu biskupa, w celu usunięcia gorszycieli ze społeczności wiernych $^{66}$. Jednocześnie, w myśl postanowień soborowych, statuty synodu z 1634 r., licząc się z możliwością znieważania wiary katolickiej, wprowadzały wobec Żydów obowiązek zamykania się w domach w czasie procesji z Najświętszym Sakramentem oraz zakazywał im opuszczania swoich domów przez cały dzień w Niedzielę Palmową, Wielki Piątek oraz podczas publicznych procesji teoforycznych ${ }^{67}$.

Poważnym zagrożeniem dla czystości wiary była działalność wędrownych kaznodziejów, będących również fałszywymi egzorcystami, głoszącymi słowo Boże bez zgody miejscowego biskupa. Biskup Łubieński wyraźnie zakazał proboszczom zatrudniania kapłanów bez uprzedniej zgody biskupa, jednocześnie polecił archidiakonom przeprowadzenie starannej kontroli w tym względzie i postanowił w uchwałach synodalnych, aby każdy kapłan, także zakonny, posiadał jurysdykcję od właściwego ordynariusza ${ }^{68}$.

Uchwały synodalne podejmowały również bardzo istotny problem, jakim było przekazywanie nauki objawionej, czyli nauczanie religijne. Miało ono służyć przede wszystkim podniesieniu poziomu religijno - moralnego w diecezji. W tej kwestii do najważniejszych

\footnotetext{
${ }^{66}$ Tamże, s. 201.

${ }^{67}$ Tamże, s. 203.

${ }^{68}$ Tamże, s. 205.
} 
form nauczania statuty zaliczały: głoszenie słowa Bożego w formie kazań przez duchownych, nauczanie katechizmu, nauczanie religii w szkołach parafialnych oraz podnoszenie poziomu wykształcenia duchowieństwa poprzez studia w seminarium.

W pierwszym rzędzie synod z 1634 r. zwracał uwagę na potrzebę głoszenia prawowiernej nauki. Nakazywał zarządcom kościołów parafialnych zakupić księgi: dekretów Soboru Trydenckiego i Katechizmu Rzymskiego oraz nauczać zgodnie z ich treścią ${ }^{69}$. Całość nauki objawionej, która miała stanowić treść przepowiadania, zawarta jest - zdaniem prawodawcy synodalnego - w czterech elementach: w Składzie Apostolskim, sakramentach, Dekalogu i Modlitwie Pańskiej. Dlatego też obowiązkiem proboszczów i innych kaznodziejów była wystarczająca znajomość prawd wiary i norm moralnych tam zawartych, a także troska o to, by treściom tym odpowiadało ich własne życie. Biskup nakazywał uwzględniać w nauczaniu kaznodziejskim zasady Katechizmu Trydenckiego, groził nawet karą bliżej nieokreśloną tym duchownym, którzy nie głosiliby słowa Bożego i nie zadośćuczyniliby obowiązkowi pouczania wiernych ${ }^{70}$.

Nakazywał również kaznodziejom, by w swoich kazaniach piętnowali praktykę pojedynków, które podlegały surowym karom kościelnym. Dotyczyło to również tych, którzy zezwalali na pojedynkowanie się w swoich dobrach ${ }^{71}$. Nadto polecał by proboszczowie i kaznodzieje sprzeciwiali się praktyce targów i jarmarków w święta, których w myśl ustaw synodalnych nie wolno było urządzać ${ }^{72}$. Częściowo nakaz ten złagodził na synodzie z 1641 r., kiedy to dopuszczał urządzanie targów, „gdyby zaszła taka potrzeba, ale tylko po uczestniczeniu we Mszy świętej, w sali prawie zamkniętej tylko o jednym wyjściu"73. Zakorzeniony zwyczaj odbywania jarmarków i targów

\footnotetext{
${ }^{69}$ Tamże, s. 202.

${ }^{70}$ Tamże, s. 201 i 204.

${ }^{71}$ Tamże, s. 202.

${ }^{72}$ Tamże.

${ }^{73}$ Synodus Dioecesana sub [...] Mathia Eubieński [...] episcopo Wladislaviensi et Pomeraniae, Wladislaviae, Anno Domini Millesimo Sexcentesimo Quadragesimo
} 
w dni świąteczne, który piętnowały synody, stanowił poważną przeszkodę w duszpasterstwie, bowiem chłopi biorący w nich udział, z reguły nie uczestniczyli we Mszy świętej. Właściciele wsi popierali ten zwyczaj obawiając się, aby ludność zależna nie udawała się na targi w dni powszednie, na czym ucierpiałaby praca pańszczyźniana ${ }^{74}$. Pozwolenie biskupa Łubieńskiego nie stało w sprzeczności z wcześniejszym jego postanowieniem zabraniającym urządzania targów w święta, ale było złagodzeniem prawa wzywającym duszpasterzy, a szczególnie kaznodziejów, do skłaniania i przekonywania wiernych, aby przenosili terminy jarmarków na dni poświąteczne. Na kanwie sprawy święcenia dni świętych prawodawca diecezjalny poruszał kwestie dotyczące nadużywania alkoholu i upijania innych. Chodziło głównie o wyrugowanie z obyczajów diecezjan tego niewłaściwego zwyczaju. Toteż uchwały synodalne z 1634 r. wzywały kaznodziejów, aby w swoim nauczaniu przypominali wiernym, iż upijanie się jest grzechem i nie licuje z obliczem chrześcijanina. Poza tym synod ten wzywał, aby proboszczowie sami piętnowali u swoich parafian praktyki nadużywania alkoholu ${ }^{75}$.

Uznając katechezę jako wyjątkową formę i drogę nauczania prawd i zasad wiary oraz moralności chrześcijańskiej, biskup Łubieński zobowiązywał wszystkich duszpasterzy do nauczania zasad wiary i postępowania chrześcijańskiego drogą katechezy. Uchwały synodalne z 1634 r. zobowiązywały proboszczów do nauczania, zarówno dorosłych jak i dzieci, pacierza i podstawowych prawd wiary. Przedmiotem tego nauczania miała być: Modlitwa Pańska, Zdrowaś Mario i Skład Apostolski, Dekalog, znaczenie i wartość Mszy świętej, przystępowania do spowiedzi i Komunii świętej oraz podstawy pobożności chrześcijańskiej. Fundamentem i podstawą tego nauczania miał być

Primo, Die Nona Mensis Junii, celebranta, Z. Chodyński, Statuta synodalia..., dz. cyt., s. 226.

${ }^{74}$ Zob. W. GóRAlski, Reformistyczne synody płockie na przełomie XVI $i$ XVII wieku, Płock 1983, s. 113.

${ }^{75}$ Acta seu Decreta et Statuta synodalia Wladislaviensis Dioecesis MDCXXXIV, die XVI Maii, et sequentibus sancita, Z. CHody Ński, Statuta synodalia..., dz. cyt., s. 202-203. 
Katechizm Trydencki ${ }^{76}$. Synod z 1641 r. zobowiązywał proboszczów i wikariuszy do nauczania Katechizmu i wyjaśniania prawd wiary, najlepiej w porze poobiedniej, w którym miały brać udział dzieci i dorośli. Nakazywał, aby duszpasterze nie odczytywali fragmentów z Katechizmu lub swoich przemówień, ale przemawiali do wiernych, bowiem słuchacze lepiej zapamiętają mówiącego niż czytającego ${ }^{77}$. Powyższe zarządzenia i zalecenia wybiegały swoją pomysłowością daleko w przyszłość, a z punktu katechetycznego były zapewne skutecznym środkiem nauczania wiernych prawd katechizmowych.

Nadto w uchwałach synodalnych z $1641 \mathrm{r}$. znajdujemy zarządzenie odnoszące się do kanonicznego badania narzeczonych przed zawarciem małżeństwa. Otóż prawodawca synodalny wzywał duszpasterzy do nauczania o sakramencie małżeństwa, jego skutkach i zobowiązaniach w myśl doktryny trydenckiej, zobowiązywał, aby narzeczeni znali przed zawarciem małżeństwa Modlitwę Pańska, Pozdrowienie Anielskie, Wyznanie wiary i Dekalog. Duszpasterze mieli obowiązek stawiać wymagania odnośnie do znajomości prawd wiary, pacierza, a jednocześnie nauczać narzeczonych przed zawarciem małżeństwa o łasce tego sakramentu i obowiązkach małżeńskich. Biskup zobowiązywał nadto narzeczonych, aby przed zawarciem małżeństwa odbyli spowiedź i przyjęli Komunię świętą, by w ten sposób z czystym sercem przystąpić do tego sakramentu ${ }^{78}$. Powyższe zarządzenie synodalne miało przyczyniać do podniesienia rangi tego sakramentu i uświadomienia duchowieństwu i wiernym świeckim roli i znaczenia stosownego przygotowania narzeczonych do przyjęcia tego sakramentu, co miało też mieć znaczenie - jak podkreślał ustawodawca synodalny - dla ich późniejszego życia religijnego w małżeństwie.

\footnotetext{
${ }^{76}$ Tamże, s. 205.

${ }^{77}$ Synodus Dioecesana sub [...] Mathia Łubieński [...] episcopo Wladislaviensi et Pomeraniae, Wladislaviae, Anno Domini Millesimo Sexcentesimo Quadragesimo Primo, Die Nona Mensis Junii, celebranta, Z. CHodý́ski, Statuta synodalia..., dz. cyt., s. 230.

${ }^{78}$ Tamże, s. 229.
} 
Pouczaniu o prawdach wiary i nauczaniu religijnemu miała służyć - zdaniem biskupa Łubieńskiego - wizyta kolędowa, którą wprowadzała w Kościele polskim przede wszystkim Pastoralna Bernarda Maciejowskiego $^{79}$. Biskup Łubieński zachęcał duszpasterzy na synodzie w 1641 r., aby podczas kolędy egzaminowali członków poszczególnych rodzin ze znajomości prawd wiary i pacierza. „Ignorantów zaś winni odpowiednio instruować, a gdy czas na to pozwalał, kierować na naukę katechizmu do świątyni ${ }^{80}$. W tym też celu biskup Łubieński na odbytym wcześniej synodzie diecezjalnym w roku 1634 zobowiązywał proboszczów do zaprowadzenia w każdej parafii kartoteki, w której duszpasterz miał zapisywać spostrzeżenia i uwagi duszpasterskie o danym parafianinie ${ }^{81}$. Miała ona być przydatna między innymi do wyeliminowania powszechnej w tamtych czasach ignorancji religijnej i katechizmowej w rodzinach chrześcijańskich, a także eliminować powstające u niektórych wiernych zobojętnienie religijne, szczególnie $\mathrm{w}$ archidiakonacie pomorskim.

Nauczanie religijne w szkołach to kolejna forma przekazywania prawd wiary i zasad moralności chrześcijańskiej, na co tak dobitnie wskazywał Sobór Trydencki ${ }^{82}$, a jednocześnie ważny element odnowy duszpasterskiej diecezji. Nauczanie szerszego ogółu wiernych w tym okresie wynikało przede wszystkim z pojawienia się i gwałtownego rozszerzania reformacji. Zapotrzebowanie na szkoły parafialne znalazło swe odbicie nie tylko w zaleceniach soborowych, ale również

\footnotetext{
${ }^{79}$ Zob. S. NAsionowski, "List pasterski” kard. Bernarda Maciejowskiego, Lublin 1992, s. 204-205.

${ }^{80}$ Synodus Dioecesana sub [...] Mathia Łubieński [...] episcopo Wladislaviensi et Pomeraniae, Wladislaviae, Anno Domini Millesimo Sexcentesimo Quadragesimo Primo, Die Nona Mensis Junii, celebranta, Z. Chodyński, Statuta synodalia..., dz. cyt., s. 230.

${ }^{81}$ Acta seu Decreta et Statuta synodalia Wladislaviensis Dioecesis MDCXXXIV, die XVI Maii, et sequentibus sancita, Z. CHodý́ski, Statuta synodalia..., dz. cyt., s. 202.

${ }^{82}$ Zob. S. K. OlcZAK, Szkolnictwo parafialne w Wielkopolsce w XVII i XVIII wieku, Lublin 1978, s. 7.
} 
w ustawodawstwie synodalnym w Polsce ${ }^{83}$. Stąd biskup Łubieński, podobnie jak inni biskupi polscy, w statutach synodu z 1641 r. podkreślał, że szkoły parafialne są miejscem szerzenia i obrony wiary katolickiej przed heretykami. Ubolewał, że liczba tych szkół znacznie w diecezji spadła, a pozostałe popadają w ruinę. Upadek szkół, zdaniem biskupa, spowodowany był między innymi złym zarządzaniem tymi placówkami. Prawodawca zwracał uwagę, że młodzież w zależności od ukształtowania przez szkołę może w przyszłości przynieść wielki pożytek lub wielką szkodę zarówno Kościołowi, jak i Rzeczypospolitej ${ }^{84}$. Apelował do odpowiedzialnych za prowadzenie tych szkół, by dołożyli starań o właściwe i należyte ich funkcjonowanie. Stosownie do wieku i swoich możliwości młodzież uczęszczająca do szkoły parafialnej winna opanować - według uchwał synodalnych - podstawowe wiadomości z gramatyki, czytania, pisania, prostej matematyki (rachunków) oraz przedmiotów humanistycznych. Biskup Łubieński nakazywał proboszczom, w trosce o poprawne nauczanie prawd wiary, aby kontrolowali zarówno treść nauczania, jak i stosowaną przez nauczyciela metodę. Proboszcz był także zobowiązany do kontrolowania tego nauczania i dołożenia starań, aby szkoły parafialne miały swój pierwotny blask. Odpowiedzialnością za nauczanie i wychowanie młodzieży synod obarczył rektorów szkół. Jednocześnie zastrzegł, że zarówno proboszczowie, jak i nauczyciele, w wypadku nie respektowania powyższych postanowień synodu będą odpowiednio i stosownie do winy ukarani. Sankcji tej jednak synod bliżej nie określił ${ }^{85}$.

\footnotetext{
${ }^{83}$ S. K. Olczak, Rola Kościoła w nauczaniu elementarnym w Polsce, Ateneum Kapłańskie t. 95(1980), s. 397.

${ }^{84}$ Synodus Dioecesana sub [...] Mathia Eubieński [...] episcopo Wladislaviensi et Pomeraniae, Wladislaviae, Anno Domini Millesimo Sexcentesimo Qoadragesimo Primo, Die Nona Mensis Junii, celebrata. Z. CHodý́ski, Statuta synodalia..., dz. cyt., s. 237. ${ }^{85}$ Tamże, s. 237-238.
} 


\section{Sprawowanie i przyjmowanie sakramentów}

Odnosząc się do zagadnienia sakramentologii i służby Bożej, jakże ważnych i istotnych elementów i form odnowy duszpasterskiej diecezji, statuty synodalne biskupa Łubieńskiego prezentują najpierw szereg norm ogólnych odnoszących się do sprawowania i przyjmowania sakramentów. W artykule De Sacramentorum administratione et de cura animarum debite exercenda uchwał synodalnych z $1634 \mathrm{r}$. prawodawca synodalny przedstawiając krótko teologię sakramentów polecił kapłanom, aby przed udzielaniem sakramentów wyjaśniali wiernym, uwzględniając ich poziom intelektualny, znaczenie i potrzebę przyjmowania sakramentów. Zobowiązywał duchowieństwo, aby nabywali książki teologiczne, $\mathrm{z}$ których czerpać będą wiedzę do wyjaśniania wiernym czym są sakramenty i jakie jest ich znaczenie dla życia doczesnego i zbawienia. Każdy duszpasterz powinien posiadać list pasterski kard. Maciejowskiego zwany Pastoralnq oraz księgę rytów, czyli agendę z rytuału piotrkowskiego, przystosowaną do rytu rzymskiego. Ponadto przypomniał proboszczom, że wolno im udzielać sakramentów tylko swoim parafianom. Wiernym $\mathrm{z}$ innych parafii można było udzielać sakramentów jedynie za zgodą ich proboszczów ${ }^{86}$. Jednocześnie wzywał duszpasterzy do troski o wiernych w udzielaniu im sakramentów, szczególnie chrztu, pokuty, Eucharystii i namaszczenia chorych ${ }^{87}$.

Na synodzie odbytym w roku 1641 biskup Łubieński przypomniał istniejący już zakaz pobierania od wiernych jakichkolwiek opłat za udzielanie sakramentów. Zakaz ten miał zapobiegać symonii, chciwości i żądzy pieniądza, które to - zdaniem ustawodawcy - odstręczały wiernych od przystępowania do sakramentów. Pozwalał jednak na składanie dobrowolnych ofiar przez wiernych za udzielanie posług

\footnotetext{
${ }^{86}$ Acta seu Decreta et Statuta synodalia Wladislaviensis Dioecesis MDCXXXIV, die XVI Maii, et sequentibus sancita, Z. CHodý́ski, Statuta synodalia..., dz. cyt., s. 201; T. KARBOWSNIK, Ofiary" iura stolae" na ziemiach polskich w latach 1285-1918. Studium historycznoprawne, Lublin 1995, s. 121-134.

${ }^{87}$ Acta seu Decreta et Statuta synodalia Wladislaviensis Dioecesis MDCXXXIV, die XVI Maii, et sequentibus sancita, Z. CHodyński, Statuta synodalia..., dz. cyt., s. 201-202.
} 
sakramentalnych. Omawiając te kwestie w artykule szóstym zatytułowanym Ne sint Sacramentorum Ministri quaestuosi biskup apelował do szafarzy sakramentów, by byli dla swoich parafian pasterzami i otoczyli ojcowską troską ludzi biednych. Przy tej okazji nakazywał duszpasterzom, aby poprzez kazania i katechezy pouczali wiernych o znaczeniu gestów, rytów i innych symboli związanych ze sprawowaniem sakramentów. Sami duchowni byli zobowiązani do pogłębiania wiedzy w tym zakresie ${ }^{88}$.

We wcześniejszej części, bo w artykule piątym Periclitantibus de vita diligenter Parochi intendant wspomnianego synodu, prawodawca wyznawał z ubolewaniem, że oprócz symonii w dziedzinie sprawowania sakramentów, wielu kapłanów używa sakramentów do niegodziwych celów, popełniając przy tym grzech świętokradztwa. Nakazał takich kapłanów surowo karać. Statut synodalny mówił, “że ktokolwiek dopuściłby się nadużycia w stosunku do Eucharystii i olejów świętych, używając sam, bądź użyczając innym, do grzesznych praktyk i zabobonnie je stosował, ściąga na siebie karę ekskomuniki ipso facto. Duchowny, który posiadał beneficjum, w takim wypadku, tracił je w trybie natychmiastowym" ${ }^{89}$. Statut powyższe normy odnosił do wszystkich rzeczy świętych przeznaczonych do kultu.

Przypominając znaczenie sakramentu chrztu w artykule synodalnym z 1641 r. zatytułowanym Periclitantibus de vita diligenter Parochi intendent biskup Łubieński wyraził troskę o właściwe i należyte udzielanie tego sakramentu, jednocześnie zobowiązał proboszczów do przestrzegania zarządzeń prawa powszechnego oraz synodów wcześniejszych $^{90}$. W artykule natomiast jedenastym Effectus Sacramentorum, maxime Confirmationis et Extremae Unctionis, auditoribus inculcent tego samego synodu, bardziej szczegółowo wyjaśniał sprawę

\footnotetext{
${ }^{88}$ Synodus Dioecesana sub [...] Mathia Łubieński [...] episcopo Wladislaviensi et Pomeraniae, Wladislaviae, Anno Domini Millesimo Sexcentesimo Quadragesimo Primo, Die Nona Mensis Junii, celebranta, Z. Chodý́ski, Statuta synodalia..., dz. cyt., s. 227.

${ }^{89}$ Tamże, s. 226.

90 Tamże.
} 
udzielania i przyjmowania sakramentu bierzmowania. Wskazywał, że sakrament ten jest przez wiernych i duchownych zapomniany i nie doceniany dla życia duchowego. Stąd wzywał wiernych, by nie zaniedbywali się w tym względzie i nakazywał, aby proboszczowie zatroszczyli się, by wszyscy z parafian przystąpili do bierzmowania ${ }^{91}$.

Omawiane synody wiele miejsca poświęciły też sakramentowi Eucharystii, od którego biskup uzależniał udaną odnowę życia duszpasterskiego w Kościele włocławskim. Pierwszy z 1634 r. w artykule De Divino Officiis rite peragendis, et de Praeparatione Sacrifficio Missae praemittenda przypominał, że Msza święta jest ofiarą ustanowioną przez Chrystusa. Stąd płynie konieczność właściwego przygotowania się przez kapłanów do jej sprawowania w odpowiednim czasie i miejscu. Przed rozpoczęciem celebracji nieodzowne jest - wskazywały statuty - uświadomienie sobie intencji, w jakiej kapłan pragnie sprawować Mszę świętą, a także odnalezienie w Mszale odpowiedniego formularza oraz przygotowanie innych przedmiotów używanych w liturgii. W czasie celebracji należało ściśle przestrzegać rubryk zawartych w Mszale. Ponadto synod zwracał uwagę na zobowiązania mszalne. Przestrzegał beneficjantów przed przyjmowaniem nowych zobowiązań mszalnych, jako formy niegodziwego zysku. Przyjęcie takich nowych zobowiązań wymagało zgody biskupa. Jednocześnie synod wzywał do wywiązywania się z dawnych zobowiązań, stosownie do klauzul erekcyjnych fundacji kościelnych. W wypadku utraty czy zmniejszenia się uposażenia lub gruntów należało odwołać się do ordynariusza, który miał wskazać sposób działania ${ }^{92}$. Drugi synod diecezjalny z 1641 r. zakazywał kapłanom odprawiania Mszy bez ministranta, zalecał przy tym angażowanie do tej funkcji przede wszystkim duchownych. Posługując przy ołtarzu byli zobowiązani

\footnotetext{
${ }^{91}$ Synodus Dioecesana sub [...] Mathia Eubieński [...] episcopo Wladislaviensi et Pomeraniae, Wladislaviae, Anno Domini Millesimo Sexcentesimo Quadragesimo Primo, Die Nona Mensis Junii, celebrate, Z. Chodý́ski, Statuta synodalia..., dz. cyt., s. 228-229.

${ }^{92}$ Acta seu Decreta et Statuta synodalia Wladislaviensis Dioecesis MDCXXXIV, die XVI Maii, sequentibus sancita, Z. Chodý́ski, Statuta synodalia..., dz. cyt., s. 200-201.
} 
przywdziać długą szatę oraz komżę. Proboszczowie zostali zobowiązani do odprawiania w soboty wotywy o Najświętszej Maryi Pannie, z wyjątkiem dni, w które nie pozwalały na to przepisy liturgiczne ${ }^{93}$.

Ustawodawstwo synodalne regulowało również sprawę udzielania i przyjmowania Komunii świętej. Synod z 1634 r. określał dyspozycje odnośnie do zanoszenia Komunii świętej chorym. Nakazywał kapłanom, aby idąc do chorych byli ubrani w komżę i stułę; byli zobowiązani nieść Najświętszy Sakrament w zasłoniętym naczynku pod baldachimem w towarzystwie ministrantów, którzy ubrani w komże, winni poprzedzać kapłana idąc z zapalonymi świecami i dzwonkami. Nakazywał również wiernym, aby brali udział w procesji do domu chorego, by w ten sposób nie zanikał zwyczaj uroczystego zanoszenia wiernym Komunii świętej. Jednocześnie wskazywał, że Komunii świętej znajdującym się w niebezpieczeństwie śmierci należy udzielać zawsze, na ile to możliwe. Dlatego duszpasterze mieli spieszyć z sakramentalną posługą nawet nocą i udzielać Komunii świętej także wówczas, gdy chory nie zachował postu eucharystycznego. Obowiązek powiadamiania proboszcza o potrzebie przyniesienia Komunii świętej do chorego spoczywał na najbliższej rodzinie chorego ${ }^{94}$.

Ten sam synod w artykule De Doctrina Christiana fidelibus populis tradenda wzywał proboszczów do przypominania wiernym o obowiązku spowiedzi i Komunii świętej wielkanocnej. Wiernym za zaniedbywanie tego obowiązku groziła kara ekskomuniki i odmowa pogrzebu katolickiego. Nadto duszpasterze byli zobowiązani nauczać i zachęcać wiernych do częstszego przystępowania do Komunii świętej. Nowością, rzadko spotykaną w innych statutach diecezjalnych, było polecenie ustawodawcy synodalnego skierowane do proboszczów, aby przygotowywali odpowiednio i gorliwie dzieci

\footnotetext{
${ }^{93}$ Synodus Dioecesana sub [...] Mathia Eubieński [...] episcopo Wladislaviensi et Pomeraniae, Wladislaviae, Anno Domini Millesimo Sexcentesimo Quadragesimo Primo, Die Nona Mensis Junii, celebranta, Z. Chodý́ski, Statuta synodalia..., dz. cyt., s. 226 i 232.

${ }^{94}$ Acta seu Decreta et Statuta synodalia Wladislaviensis Dioecesis MDCXXXIV, die XVI Maii, et sequentibus sancita, Z. CHody Ński, Statuta synodalia..., dz. cyt., s. 201.
} 
do przystąpienia do pierwszej spowiedzi i Komunii świętej. Byli oni zobowiązani nie dopuszczać dzieci do przyjmowania Komunii, przed dojściem do pełnego używania rozumu, jeżeli wpierw nie zostały pouczone o naturze i doniosłości Eucharystii i zdały egzamin z zakresu podstawowych prawd wiary ${ }^{95}$.

Artykuł Cultum et frequentationem ss. Eucharistie synodu z 1641 r. regulował sprawę obowiązku Komunii świętej wielkanocnej. Przypominając zarządzenia Stolicy Apostolskiej i synodów prowincjalnych, nakazywał odbywanie spowiedzi i Komunii wielkanocnej od Niedzieli Palmowej do drugiej niedzieli po Wielkanocy włącznie. Proboszcz w myśl zarządzenia synodalnego - miał obowiązek prowadzenia kartoteki parafialnej, do czego zobowiązywał synod wcześniejszy $\mathrm{z}$ roku $1634^{96}$, winien zanotować w niej nazwiska zaniedbujących Komunię wielkanocną i zadenuncjować opornych ordynariuszowi miejsca lub jego wizytatorowi. Denuncjację tę należało pominąć, gdy obowiązek Komunii świętej został odłożony za poradą lub z zakazu spowiednika. Winni zaniedbywania tego obowiązku mieli być upominani, gdyby zaś trwali w nieposłuszeństwie, mieli być pozbawieni przez proboszczów prawa wstępu do kościoła, a w wypadku śmierci prawa do pogrzebu katolickiego ${ }^{97}$.

Uchwały synodalne regulowały również sprawę przechowywania i kultu Eucharystii. Synod z 1634 r. w rozdziale De sacramentorum administratione et de cura animarum debite exercenda zobowiązywał proboszczów do przechowywania Eucharystii w tabernakulum umieszczonym na ołtarzu głównym, przed którym winna palić się

\footnotetext{
${ }^{95}$ Tamże, s. 202.

${ }^{96}$ Acta seu Decreta et Statuta synodalia Wladislaviensis Dioecesis MDCXXXIV, die XVI Maii, et sequentibus sanhita, Z. CHodyński, Statuta synodalia..., dz. cyt., s. 202.

${ }^{97}$ Synodus Dioecesana sub [...]Mathia Eubieński [...] episcopo Wladislaviensi et Pomeraniae, Wladislaviae, Anno Domini Millesimo Sexcentesimo Quadragesimo Primo, Die Nona Mensis Junii, celebrata., Z. CHodý́ski, Statuta synodalia..., dz. cyt., s. 228.
} 
wieczna lampka ${ }^{98}$. Synod natomiast z $1641 \mathrm{r}$. w artykule trzecim Modus asservandae Divinissimae Eucharistiae et tractandae podawał bardzo drobiazgowe przepisy odnośnie do urządzenia tabernakulum. Zgodnie $\mathrm{z}$ wolą prawodawcy, powinno ono być wykonane $\mathrm{z}$ trwałego materiału, umieszczone w głównym ołtarzu i umocowane do niego na stałe. Miało być wybite wewnątrz jedwabnym materiałem. Należało je dodatkowo ozdobić od wewnątrz i zewnątrz, nakrywając je tzw. konopeum. W tabernakulum nie wolno było przechowywać czegokolwiek poza Najświętszym Sakramentem. Ponieważ zdarzały się zaniedbania co do sprawy renowacji Sanctissimum i w tabernakulach przechowywano nieświeże postacie eucharystyczne, synod postanawiał, że renowacja ich miała się odbywać co piętnaście dni w porze zimowej i co osiem dni w letniej ${ }^{99}$. W trosce o bezpieczeństwo Najświętszego Sakramentu, klucz od tabernakulum miał być przechowywany przez proboszczów i wikariuszy, z zakazem udostępniania komukolwiek z osób świeckich ${ }^{100}$. Dla ożywienia natomiast kultu eucharystycznego i wyproszenia opieki Bożej nad ojczyzną - co warte jest podkreślenia i zauważenia - biskup Maciej Łubieński na synodzie w 1634 r., w artykule De publicatione Supplicationem pro praesentibus Reipublicae necessitatibus wprowadził w diecezji tzw. nabożeństwo czterdziestogodzinne, o którym proboszczowie mieli pouczać i wyjaśniać jego wartość oraz znaczenie dla wiernych, Kościoła i Polski, co

\footnotetext{
${ }^{98}$ Acta seu Decreta et Statuta synodalia Wladislaviensis Dioecesis MDCXXXIV, die XVI Maii, et sequentibus sancita, Z. CHodý́ski, Statuta synodalia..., dz. cyt., s. 201.

${ }^{99}$ Synodus Dioecesana sub [...]Mathia Łubieński [...] episcopo Wladislaviensi et Pomeraniae, Wladislaviae, Anno Domini Millesimo Sexcentesimo Quadragesimo Primo, Die Nona Mensis Junii, celebrata., Z. Chodý́ski, Statuta synodalia..., dz. cyt., s. 231.

${ }^{100}$ Synodus Dioecesana sub [...] Mathia Eubieński [...] episcopo Wladislaviensi et Pomeraniae, Wladislaviae, Anno Domini Millesimo Sexcentesimo Quadragesimo Primo, Die Nona Mensis Junii, celebrata, Z. CHody Ński, Statuta synodalia..., dz. cyt., s. 225-226.
} 
również było ważnym elementem odnowy duszpasterskiej i religijnej wiernych ${ }^{101}$.

Jeżeli chodzi o sprawowanie sakramentu pokuty, to w dyspozycjach synodu z 1634 r. znajdujemy zarządzenie odnoszące się do spowiedzi kapłanów. Otóż synod polecał, aby proboszczowie nie odbywali spowiedzi u swoich wikariuszy. Wolno im to było czynić tylko wyjątkowo, gdyby napotkali na przeszkody w dotarciu do innego spowiednika, dziekana lub jego zastępcy. Dla ułatwienia spowiedzi kapłanom, ustawodawca polecił dziekanom, aby postarali się o pewną ilość spowiedników w dekanatach, do których w każdej chwili kapłan mógłby się dostać. Kto by zaniedbywał się w odprawianiu spowiedzi, miał być ukarany grzywną w wysokości trzech marek. Opornych i notorycznie zaniedbujących spowiedź, dziekan miał przekazywać do ukarania biskupowi ${ }^{102}$.

Bardzo zdecydowanie i jednoznacznie biskup Łubieński regulował sprawę posiadania jurysdykcji do spowiadania przez zakonników. Ponieważ wielu zakonników na terenie diecezji powoływało się na specjalne przywileje, spowiadając i rozgrzeszając nawet z cenzur zastrzeżonych biskupowi, nie mając do tego upoważnienia, ten sam synod w artykule De Regularibus postanawiał ipso facto ekskomunikować tych zakonników, którzy nie mając odpowiedniego pozwolenia, rozgrzeszali z rezerwatów biskupich i tych, które zamieszczała bulla Coenae Domini. Dla łatwiejszego zapoznania się z rezerwatami, synod zachęcał zakonników, aby zapoznali się z zamieszczoną w statutach synodalnych bullą papieską Coenae Domini ${ }^{103}$.

W artykule De publicatione Bullae Coenae Domini et Casuum Sedi Episcopali reservatorum tegoż synodu, prawodawca celem także odnowy duszpasterskiej diecezji zobowiązywał proboszczów, aby pouczali wiernych w Wielki Czwartek o karach kościelnych

\footnotetext{
${ }^{101}$ Acta seu Decreta et Statuta synodalia Wladislaviensis Dioecesis MDCXXXIV, die XVI Maii, et sequentibus sancita, Z. CHodý́ski, Statuta synodalia..., dz. cyt., s. 219.

102 Tamże, s. 200.

103 Tamże, s. 207.
} 
zamieszczonych we wspomnianej bulli i sami je dobrze znali oraz stosowali podczas spowiadania. Podał również listę 14 rezerwatów biskupich, z których poza niebezpieczeństwem śmierci, żaden kapłan bez pisemnej zgody biskupa nie mógł udzielić rozgrzeszenia. Na liście tej znalazły się następujące grzechy: 1) umyślne niszczenie beneficjum, 2) nie mianowanie w odpowiednim czasie beneficjata, 3) niszczenie pobożnych legatów, 4) zagarnięcie majątku po zmarłym duchownym bez zgody biskupa, 5) świętokradztwo i krzywoprzysięstwo, 6) spędzenie płodu, 7) rabunek i uprowadzenie, 8) publiczny konkubinat lub cudzołóstwo, 9) porwanie i gwałt na zakonnicy, 10) kaziroctwo w pierwszym i drugim stopniu, 11) przywłaszczenie sobie dziesięcin lub innego majątku kościelnego, 12) pobicie, wyrzucenie i gwałt na rodzicach, 13) profanacja imienia Bożego i Świętych, 14) publiczne i notoryczne bluźnierstwo ${ }^{104}$. W swoim drugim synodzie diecezjalnym z 1641 r., prawodawca synodalny ponownie w artykule De Sacramenti Poenitentiae necessitate et modo populum instruant, zobowiązywał do przestrzegania i zachowywania przepisów dotyczących udzielania i przyjmowania sakramentu pokuty, który jest "szczęśliwą deską ratunku dla chrześcijanina"105.

Statuty synodalne Łubieńskiego, podobnie jak to czyniły wcześniejsze, poruszały z całą mocą - zgodnie z soborowym dekretem "Cum adolescentium aetas"106 kwestię seminarium duchownego, jako właściwej i zalecanej instytucji kształcenia kandydatów do kapłaństwa, która jednocześnie miała służyć odnowie duszpasterskiej diecezji. W myśl artykułu dwunastego De Seminariis synodu z 1641 r. biskup wskazywał, że seminarium powinno mieć program formacji duchowej i intelektualnej, a także odpowiedni regulamin, nad zachowywaniem których miał czuwać rektor. Kandydaci do święceń byli

\footnotetext{
104 Tamże, s. 205-206.

${ }^{105}$ Synodus Dioecesana sub [...] Mathia Łubieński [...] episcopo Wladislaviensi et Pomeraniae, Wladislaviae, Anno Domini Millesimo Sexcentesimo Quadragesimo Primo, Die Nona Mensis Junii, celebrata, Z. CHodý́ski, Statuta synodalia..., dz. cyt., s. 228 .

${ }^{106}$ Conc. Trid., sess. XXIII, c. 18 de ref.
} 
zobowiązani, by przynajmniej przez rok kształcili się w seminarium, zdobywając właściwe przygotowanie do przyjęcia święceń. Do święceń kapłańskich wolno było dopuszczać tylko tych, którzy przez dwa lata uczyli się teologii moralnej i kazuistyki oraz przedstawili egzaminatorowi zaświadczenie o zdanych egzaminach. W ramach egzaminu dopuszczającego do święceń należało również złożyć egzamin ze śpiewu gregoriańskiego. Biskup polecił egzaminatorom sumiennie odpytywać kandydatów. Jednocześnie biskup określał uprawnienia rektora seminarium, podkreślając, że to on jest kompetentny do wymierzania kar, tym którzy łamią seminaryjny regulamin. Nie można też było dopuszczać do święceń kapłańskich bez pozytywnej opinii rektora seminarium ${ }^{107}$. Według biskupa Łubieńskiego i jego statutów synodalnych, bezpośredni związek z odnową duszpasterstwa w diecezji miało funkcjonowanie instytucji kształtującej i przygotowującej przyszłych kapłanów przede wszystkim do pracy w duszpasterstwie.

Ten sam synod zakazywał udzielania święceń tym kandydatom, którzy nie mieli zapewnionego wcześniej dostatecznego utrzymania. Każdy kandydat do święceń musiał prawnie wykazać się, iż posiada odpowiednie beneficjum, wystarczające do godziwego utrzymania, względnie pewną prowizję udzieloną mu przez kościól, który go przyjmie lub majątek własny. Tytuł kanoniczny stałego i prawnego zabezpieczenia godziwego i wystarczającego utrzymania kandydata do święceń nie mógł być fikcyjny. W przeciwnym razie powodował suspensę od wykonywania przyjętych święceń. Ci natomiast, którzy w sposób podstępny poświadczyli ten fikcyjny tytuł, zaciągali ekskomunikę ${ }^{108}$.

Omawiane synody wymieniały także potrzebne sprzęty liturgiczne do sprawowania służby Bożej, nakazując aby były przechowywane w należytym porządku i czystości. Szczególną uwagę zwracano na

\footnotetext{
${ }^{107}$ Synodus Dioecesana sub [...] Mathia Łubieński [...] episcopo Wladislaviensi et Pomeraniae, Wladislaviae, Anno Domini Millesimo Sexcentesimo Quadragesimo Primo, Die Nona Mensis Junii, celebrata, Z. Chodý́ski, Statuta synodalia..., dz. cyt., s. 235.

108 Tamże, s. 235-236.
} 
utrzymanie w należytej czystości bielizny kielichowej: korporałów, palek i puryfikaterzy. Pranie owej bielizny zostało zastrzeżone diakonom i kapłanom, a dokonywać tego mieli w sakrarium, w specjalnie do tego przeznaczonych naczyniach ${ }^{109}$. Jednocześnie prawodawca synodalny zdecydowanie zabraniał proboszczom przechowywania w świątyniach rzeczy nie mających nic wspólnego z kultem Bożym ${ }^{110}$.

\section{Dyscyplina i karność duchowieństwa}

Czasy w jakich biskup Łubieński kierował diecezją kujawsko-pomorską wymagały reformy duchowieństwa, poprzez którą - jak to wskazywał Sobór Trydencki ${ }^{111}$ - miały zostać wzmocnione fundamenty do reformowania i budowania nowego oblicza Kościoła i jego działalności duszpasterskiej. Stąd uchwały synodalne sporo miejsca poświęcały kwestiom dyscyplinarnym duchowieństwa, jego życiu, obyczajom i prowadzenia duszpasterstwa. Jak wspomniano wcześniej, dużą wagę synody przywiązywały do rezydencji duchowieństwa, która miała być gwarantem gorliwej pracy duszpasterskiej i odnowy Kościoła. W związku z tym na synodzie z 1641 r. znajdujemy zarządzenie według którego nieobecność proboszcza w parafii nie mogła przekraczać dwóch, najwyżej trzech miesięcy w ciągu roku, czy to bez przerwy, czy też licząc czas z przerwami. Przyczyny opuszczenia parafii powinny być zakomunikowane obowiązkowo własnemu ordynariuszowi, który powinien wyrazić pisemną zgodę na pobyt proboszcza poza parafią. Duszpasterz opuszczający swoją parafię miał obowiązek zapewnić wiernym właściwą opiekę duszpasterską, mając na względzie dobro powierzonego kościoła. W żadnym wypadku zaznaczał synod z 1641 r. - proboszczowie nie powinni opuszczać

\footnotetext{
${ }^{109}$ Acta seu Decreta et Statuta synodalia Wladislaviensis Dioecesis MDCXXXIV, die XVI Maii, et sequentibus sanhita, Z. CHodyński, Statuta synodalia..., dz. cyt., s. 202.

${ }^{110}$ Synodus Dioecesana sub [...] Mathia Eubieński [...] episcopo Wladislaviensi et Pomeraniae, Wladislaviae, Anno Domini Millesimo Sexcentesimo Quadragesimo Primo, Die Nona Mensis Junii celebrata, Z. Chodý́ski, Statuta synodalia..., dz. cyt., s. 232.

${ }^{111}$ Conc. Trid., sess. XXV, c. 2 de ref.
} 
swoich parafii w okresie Adwentu, Wielkiego Postu i uroczystych świąt kościelnych: Bożego Narodzenia, Wielkanocy, Zielonych Świąt, Bożego Ciała, Patrona kościoła i rocznicy jego poświęcenia. W sposób szczególny, zalecał ustawodawca synodalny - duszpasterze nie powinni opuszczać swoich parafii i wiernych w okresie panującej epidemii. W takiej chwili „ich obowiązkiem było niesienie wiernym duchowej pomocy, wzywanie ludu do korzystania z sakramentu pokuty i Eucharystii, zaopatrywanie chorych na śmierć, nawet $\mathrm{z}$ narażeniem własnego życia"112.

Powyższe zarządzenia, powodujące daleko idące ograniczenie ruchów beneficjatów, były próbą urzeczywistnienia obowiązku rezydencji w diecezji, do której Sobór Trydencki przywiązywał wielką wagę. Świadczyły jednocześnie pozytywnie o zamiarach ustawodawcy synodalnego podejmującego wysiłki zmierzające do naprawy dyscypliny duchowieństwa, jak też stanowiły bardzo ważny element owocnego prowadzenia duszpasterstwa, co miało bezpośrednie przełożenie na odnowę duszpasterską diecezji.

Wskutek niedbalstwa proboszczów albo z powodu przywłaszczania sobie dochodów kościelnych przez osoby świeckie, wiele kościołów w diecezji, szczególnie w jej części pomorskiej, znajdowało się w upadku. Wizytacje biskupa Łubieńskiego wykazały, że duchowni żądni zysków nie tylko kumulowali beneficja, ale nie troszczyli się o naprawę kościołów i budynków do nich przynależnych, zaniedbywali także ich wystrój wewnętrzny Stąd synody z 1634 i 1641 r. bardzo zdecydowanie i jednoznacznie przypominały przepisy prawne w zakresie nabywania beneficjów, ich prawnego objęcia oraz nadania przez kompetentną władzę kościelną, właściwego administrowania, a także ich ścisłego związania $\mathrm{z}$ urzędem duszpasterskim ${ }^{113}$.

\footnotetext{
${ }^{112}$ Synodus Dioecesana sub [...] Mathia Łubieński [...] episcopo Wladislaviensi et Pomeraniae, Wladislaviae, Anno Domini Millesimo Sexcentesimo Quadragesimo Primo, Die Nona Mensis Junii, celebrata. Z. CHodyński, Statuta synodalia..., dz. cyt., s. 237-238.

${ }^{113}$ Tamże, s. 239; Acta seu Decreta et Statuta synodalia Wladislaviensis Dioecesis MDCXXXIV, die XVI Maii, et sequentibus sanhita, Z. CHoDy ŃsKI, Statuta synodalia..., dz. cyt., s. 204.
} 
W artykule De conservatione ecclesiarum et iuribus ipsarum synodu z 1641 r. znajdujemy zarządzenie zezwalające beneficjatom w archidiakonacie pomorskim na kumulację beneficjów. Otóż jednemu kapłanowi wolno było administrować dwoma lub trzema parafiami, ze względu na fakt, że parafie w części pomorskiej diecezji były bardzo biedne i słabo uposażone, stąd nie były w stanie utrzymać proboszcza. Wynikało to również z faktu, że w archidiakonacie pomorskim brakowało kapłanów, a wiele kościołów pozbawionych było proboszczów. Dlatego biskup zlecał opiekę nad tymi wakującymi kościołami i wiernymi proboszczom sąsiednim, po uprzednim uzyskaniu przez nich władzy na piśmie od ordynariusza lub konsystorza ${ }^{114}$.

$\mathrm{W}$ nurt zagadnień mających wpływ na odnowienie duszpasterstwa miały również zarządzenia synodalne zawarte $\mathrm{w}$ rozdziale trzecim wspomnianego synodu, zatytułowanym De vita et honestate Cleri, podzielonym na trzynaście artykułów, a odnoszące się do życia, obyczajów i postępowania duchowieństwa. Na początku, prawodawca przypominał, że wygląd zewnętrzny kapłana powinien być świadectwem przyjętych święceń. W związku z tym, każdy duchowny zobowiązany był do noszenia tonsury oraz odpowiednio utrzymanych włosów, wąsów i brody. Właściwym ubiorem miał być czarny strój - czysty, odpowiedniego kroju, bez ozdób, sięgający do kostek. Kiedy duchowny przebywał w podróży, był zwolniony od noszenia tego stroju ${ }^{115}$. Następnie stwierdzał, że „każdy kapłan ma być w myśli czysty, w pracy solidny, w milczeniu dyskretny, oddany rozmyślaniu, ma być dobroczyńcą, wrogiem błędów, a w życiu, obyczajach i stroju zawsze uczciwy". Dlatego też na tych zasadach - stwierdzał prawodawca synodalny - winno opierać się życie osobiste każdego kapłana, jak i wzajemne współżycie duchowieństwa. Zobowiązywał następnie duchownych do odmawiania godzin kanonicznych z brewiarza rzymskiego i stosowanie się jednocześnie do rubryk diecezjalnych, a także

\footnotetext{
114 Tamże, s. 232-233.

115 Tamże, s. 237.
} 
pogłębiania swojej wiedzy teologicznej przez czytanie odpowiedniej lektury teologicznej i medytację Pisma Świętego ${ }^{116}$.

Życie duchowieństwa powinna charakteryzować prostota i skromność, unikanie wszelkich form próżności i zbytku. Prawodawca piętnował pijaństwo duchownych i korzystanie w nadmiarze z obfitości stołu. Zabraniał uczęszczania do karczm, brania udziału w polowaniach i zajmowania się handlem oraz wracania na plebanię po godzinie pierwszej w nocy. Zalecał powściągliwość, umiar, dobry przykład. Duchownego, który nadużywał często alkoholu (pijaka) biskup zalecał wyłączać ze społeczności na okres trzydziestu dni, a nawet poddawać karze cielesnej, nie określał jednak jakiej ${ }^{117}$. Duszpasterze powinni unikać wszelkich form chciwości, która koncentrując uwagę kapłana na sprawach doczesnych, jest źródłem zła. Dlatego szczególną uwage prawodawca synodalny zwracał na właściwe użytkowanie dochodów beneficjalnych oraz pieniędzy przeznaczonych na ozdobę kościoła i jałmużnę dla biednych. Zgodnie z intencją ofiarodawców, wszelkie dobra powinny być wykorzystywane na właściwe cele, a nie na wspieranie domowników, krewnych czy innych osób bliskich duchownemu. Synod potępiał wszelkie przejawy symonii, a także lichwy w życiu duchowieństwa, obwarowując je karami kościelnymi ${ }^{118}$.

W artykule Familiaritas foeminarum vitanda prawodawca z kolei przypominał wcześniejsze postanowienia dotyczące relacji duchownych z kobietami. Wzywał duchowieństwo do unikania poufałości z kobietami, piętnował konkubinat, zakazywał surowo utrzymywania w domach osób duchownych - lub poza nimi - konkubin, albo innych podejrzanych kobiet, zwłaszcza młodych, a nawet tych które służą im pomocą. Do pracy na plebani powinni być raczej używani mężczyźni. Gdy konieczność tego wymagała oraz czas choroby, mogły być brane do posług kobiety, ale starsze wiekiem i cieszące się dobrą opinią i nienagannością obyczajów. Synod zachęcał kapłanów, aby swoim życiem i postępowaniem nie dawali okazji do zgorszenia,

\footnotetext{
116 Tamże, s. 236.

117 Tamże, s. 236-237.

118 Tamże, 237-238.
} 
plotek czy intryg ze strony otoczenia ${ }^{119}$. Synod zaś z 1634 r. nakazywał towarzyszenie biskupowi, archidiakonowi czy też wyznaczonemu przez biskupa wizytatorowi, w czasie wizytacji. Wizytacje te miały na celu „zachowanie czystości wiary i umocnienie obyczajów chrześcijańskich wśród wiernych"120.

Wiele miejsca synody biskupa Łubieńskiego poświęcały przeprowadzaniu wizytacji parafii przez dziekana, co także miało być formą odnowy duszpasterstwa. Dziekani będąc bezpośrednimi przełożonymi proboszczów z ramienia biskupa, mogli najlepiej zbadać potrzeby i bolączki parafii, a tym samym mobilizować proboszczów do gorliwej pracy duszpasterskiej. Celem takiej wizytacji parafialnej było czuwanie nad stanem moralnym i materialnym parafii. Swoje wizytacje byli zobowiązani przeprowadzać raz w roku, a sprawozdanie $\mathrm{z}$ niej przesłać biskupowi ${ }^{121}$. Czuwanie nad stanem moralnym parafii obejmowało badanie życia moralnego i obyczajów duchowieństwa, czuwanie nad przestrzeganiem rezydencji duchowieństwa, znajomości teologii i prawa kanonicznego, co wiązało się z obowiązkiem egzaminowania duchowieństwa z zakresu teologii moralnej, dogmatycznej, prawa kanonicznego, sakramentu pokuty, liturgiki, głoszenia Słowa Bożego, udzielania sakramentów, zwłaszcza umierającym, sprawowania kultu Bożego, chowaniem zmarłych ${ }^{122}$.

Innym - ważnym obowiązkiem dziekańskim mającym duży wpływ na odnowę duszpasterstwa - było organizowanie i przeprowadzanie

\footnotetext{
${ }^{119}$ Tamże, s. 237.

${ }^{120}$ Acta seu Decreta et Statuta synodalia Wladislaviensis Dioecesis MDCXXXIV, die XVI Maii, et sequentibus sancita, Z. CHodyŃski, Statuta synodalia..., dz. cyt., s. 200.

${ }^{121}$ Synodus Dioecesana sub [...] Mathia Łubieński [...] episcopo Wladislaviensi et Pomeraniae, Wladislaviae, Anno Domini Millesimo Sexcentesimo Quadragesimo Primo, Die Nona Mensis Junii, celebrata. Z. Chodyński, Statuta synodalia..., dz. cyt., s. 238.

${ }^{122}$ Acta seu Decreta et Statuta synodalia Wladislaviensis Dioecesis MDCXXXIV, die XVI Maii, et sequentibus sancita, Z. CHOdyŃski, Statuta synodalia..., dz. cyt., s. 200; Synodus Dioecesana sub [...] Mathia Łubieński [...] episcopo Wladislaviensi et Pomeraniae, Wladislaviae, Anno Domini Millesimo Sexcentesimo Quadragesimo Primo, Die Nona Mensis Junii, celebrate, Tamże, s. 236 i 238.
} 
zebrań dekanalnych, które miały odgrywać ważną rolę w ożywieniu i podtrzymywaniu ducha kapłańskiego wśród duchowieństwa dekanatu, jego dyscypliny i karności oraz zaradzania potrzebom duszpasterskim i realizowania postanowień synodalnych. Dlatego synod z 1634 r. nakazywał, aby kongregacje dekanalne składały się z dwóch części: ascetycznej (Msza z kazaniem) i obradowej. Podczas drugiej części zebrania, prowadzonej przez dziekana, przedmiotem obrad miały być sprawy duszpasterskie. Najpierw dziekani sprawdzali świadectwa ustanowienia kanonicznego proboszczów, bądź inwestytury, a co za tym szło, sprawy jurysdykcji słuchania spowiedzi i głoszenia kazań. Każdy proboszcz miał obowiązek podczas takiego zebrania dać sprawozdanie ze swego życia kapłańskiego i życia parafii. Jeżeli dziekani zauważyli u jakiegoś duchownego zaniedbania, czy to w życiu duchowym czy administrowania parafią, mieli prawo upominać, a jeżeli zaniedbanie to się powtarzało, to nakładali naganę. Gdy natomiast miały miejsce większe występki i zgorszenia w dekanacie, dziekan - po zbadaniu całej sprawy - był zobowiązany o wszystkim powiadomić pisemnie biskupa. Jednocześnie synody polecały dziekanom troskę o utrzymywanie wśród duchowieństwa swoich okręgów ducha jedności i miłości ${ }^{123}$.

Ten sam synod, pragnąc zreformować życie zakonne i poprawić relacje pomiędzy duchowieństwem zakonnym a diecezjalnym, co też miało walor duszpasterski, postanowił szerzej zająć się sprawą zakonów i ustalić normy łagodzące spory. Uczynił to w artykule De Regularibus. Najpierw ustawodawca synodalny zwracał uwagę opatom i przełożonym zakonnym oraz zakonnikom na obowiązek życia zgodnego z regułą zakonną, a następnie obowiązek posiadania jurysdykcji do spowiadania od swego właściwego ordynariusza ${ }^{124}$.

\footnotetext{
${ }^{123}$ Acta seu Decreta et Statuta synodalia Wladislaviensis Dioecesis MDCXXXIV, die XVI Maii, et sequentibus sancita, Z. CHody Ński, Statuta synodalia,..., dz. cyt., s. 200 i 231.

${ }^{124}$ Acta seu Decreta et Statuta synodalia Wladislaviensis Dioecesis MDCXXXIV, die XVI Maii, et sequentibus sancita, Z. CHodý́ski, Statuta synodalia..., dz. cyt., s. 206.
} 
Ponieważ wielu zakonników na terenie diecezji spowiadało, a nawet rozgrzeszało z cenzur zastrzeżonych biskupowi czy ekskomunikowanych, nie mając jurysdykcji biskupiej, a tylko powołując się na specjalne przywileje, synod postanowił karać ekskomuniką tych zakonników, którzy udzielali rozgrzeszenia nie posiadając jurysdykcji lub zezwolenia biskupa. Zakonnika nie zachowującego przepisów prawa - stwierdzał ustawodawca synodalny - nie mogły chronić żadne egzempcje, ani przywileje. Taka sama kara miała spotkać tych zakonników, którzy duchownym lub świeckim udzielali Ostatniego Namaszczenia lub Komunii świętej, błogosławili związki małżeńskie i udzielali innych sakramentów nie posiadając odpowiedniego zezwolenia od miejscowego ordynariusza. Mogli to czynić, jeżeli mieli stosowne zezwolenie lub specjalny przywilej ${ }^{125}$.

\section{Regulacje w sprawach majątkowo-administracyjnych i sądowych}

Obok ustawodawstwa synodalnego biskupa Łubieńskiego odnoszącego się do przekazu wiary i nauczania, administrowania sakramentami, zarządu beneficjami, sprawowania urzędów kościelnych, karności i dyscypliny duchowieństwa, jego rezydencji oraz obyczajów i życia religijnego wiernych, które miało kształtować i reformować duszpasterstwo w diecezji, były sprawy majątkowe, administracyjne i sądowe, które niejako tylko pośrednio miały wpływ na działalność duszpasterską, jednakże stanowiły ważny element funkcjonowania Kościoła partykularnego w sferze materialno-gospodarczej. Stąd możemy znaleźć w uchwałach synodów zarządzenia zobowiązujące proboszczów o przekazywanie stosownych funduszy na rzecz utrzymania i funkcjonowania seminariów duchownych we Włocławku i Szotland koło Gdańska ${ }^{126}$. Zarządzenia podejmowane na synodach,

\footnotetext{
125 Tamże.

126 Tamże, s. 214-215; Synodus Dioecesana sub [...] Mathia Łubieński episcopo Wladislaviensi et Pomeraniae, Wladislaviae, Anno Domini Millesimo Sexcentesimo Quadragesimo Primo, Die Nona Mensis Junii, celebrate, Z. Chodyński, Statuta synodalia..., dz. cyt., s. 235-236.
} 
w porozumieniu z kapitułą katedralną, służyły zabezpieczeniu środków finansowych na kształcenie przyszłych kapłanów. Nie zawsze były one wystarczające i łatwe do uzyskania, dlatego biskup sięgał nawet do środków karnych i sądowych.

Uchwały synodalne zawierały również regulację prawną odnoszącą się do majątków po zmarłych duchownych. Otóż pragnąc usunąć z życia diecezji szerzący się proceder grabieży majątków po zmarłych duchownych, biskup Łubieński na synodzie odbytym w 1634 r. podawał szczegółowe przepisy dotyczące sporządzania i wykonywania testamentów kapłańskich. Nakazywał, by po śmierci kapłana, dziekan w obecności innego kapłana oraz radcy, sołtysa lub miejscowego urzędnika, kilku wiarygodnych ludzi z parafii oraz spadkobierców spisał i zabezpieczył cały inwentarz po zmarłym. Dziekan następnie powinien powiadomić o tym biskupa lub oficjała. Synod surowo zabraniał krewnym zmarłego i patronom kościołów samowolnego rozdzielania mienia po zmarłym kapłanie. Za grabież majątku po zmarłym groziła ekskomunika ipso facto. W wypadku duchownych zmarłych bez testamentu synod postanowił, że po odliczeniu kosztów pogrzebu, część majątku miała być przeznaczona dla służby kościelnej, część na spłacenie ewentualnych długów, część na msze św. za zmarłego, część dla rodziny zmarłego, a reszta na potrzeby szpitala dla chorych kapłanów ${ }^{127}$.

Biskupowi Łubieńskiemu należy przypisać podjęcie zaniechanej sprawy założenia schroniska (domu opieki) dla księży emerytów. Podjął tę kwestię również na powyższym synodzie. W artykule zatytułowanym De Hospitali pro pauperibus sensibus et infirmis Clericis erigendo nakazywał, aby dziekani zbierali w ciągu każdego roku od każdego proboszcza po dziesięć groszy, a od wikariusza po pięć groszy na powyższy cel. Pieniądze te należało przekazać na ręce specjalnie w tym celu wyznaczonego prokuratora. Duchowni, którzy nie wykonali tego obowiązku mieli być pociągnięci do odpowiedzialności

\footnotetext{
${ }^{127}$ Acta seu Decreta et Statuta synodalia Wladislaviensis Dioecesis MDCXXXIV, die XVI Maii, et sequentibus sancita, Z. CHodyński, Statuta synodalia..., dz. cyt., s. 214 .
} 
karnej. Wszelkie dobra i majątki po zmarłych duchownych bez testamentu miały być przeznaczone na ten cel, po potrąceniu - jak już zaznaczono - wydatków związanych z pogrzebem zmarłego kapłana, ewentualnych długów, przeznaczeniu części majątku dla rodziny i służby kościelnej oraz na odprawienie Mszy świętej za zmarłego ${ }^{128}$. Sam biskup ze swej strony zobowiązał się, na posiedzeniu kapituły włocławskiej, składać na potrzeby domu specjalny zasiłek roczny ze swych dóbr oraz przeznaczył na ten cel połowę domu we Włocławku, który w tym czasie nie był zamieszkały przez ojców reformatów ${ }^{129}$. Synod zaś z 1641 r. utrzymując poprzednie fundusze, uchwalił dalsze dotacje na budowę szpitala dla duchownych. Pozwoliło to na otwarcie w 1641 r. schroniska-szpitala we Włocławku dla księży z części kujawskiej diecezji. W tym samym roku został erygowany taki sam dom w Starogardzie dla duchowieństwa części pomorskiej diecezji ${ }^{130}$. Nie była jednakże do końca jasno sprecyzowana sprawa uposażenia tego domu, dopiero później zostały wyznaczone pewne czynsze i dochody na utrzymanie tego domu ${ }^{131}$.

W trosce o zabezpieczenie majątku kościelnego synody Łubieńskiego nakazywały administratorom kościołów odnalezienie wszelkich dokumentów potwierdzających nadanie kiedykolwiek ich kościołom jakichkolwiek fundacji, praw i przywilejów. Zaginięcie tych dokumentów - zdaniem prawodawcy synodalnego - przyczyniło się do upadku wielu fundacji, a tym samym do znacznego uszczuplenia stanu materialnego wielu parafii. Nadto każdy obejmujący beneficjum był zobowiązany sporządzić inwentarz rzeczy i dóbr z nim

\footnotetext{
${ }^{128}$ Tamże.

${ }^{129}$ J. FIJAŁEK, Statuty kapituły katedralnej włocławskiej z materiałów przysposobionych przez ks. Stanisława Chodyńskiego..., dz. cyt., s. 293-294.

${ }^{130} \mathrm{O}$ domu-szpitalu dla chorych i starszych kapłanów wspominał biskup Łubieński w roku $1640 \mathrm{w}$ swoim piśmie zwołującym synod archidiakonatu pomorskiego na 23 września 1640 r. Groził w nim karą zapłaty dziesięciu dukatów złotych na szpital w Starogardzie przez tych duchownych, którzy nie przybędą na synod. Zob. Archiwum Diecezji Włocławskiej, Akta Biskupów Kujawsko-Pomorskich, N. 21 (40) k. 790.

${ }^{131}$ Z. CHodý́ski, Statuta synodalia..., dz. cyt., s. XXXV-XXXVI.
} 
związanych. Tak spisany i opisany majątek każdego beneficjum, łącznie $\mathrm{z}$ dziesięcinami i innymi dochodami, należało przesłać w ciągu sześciu miesięcy ordynariuszowi lub jego wikariuszowi. Inwentarz ten miał być corocznie odnawiany i uzupełniany oraz przesyłany do Kurii ${ }^{132}$.

W sprawach sądowych znajdujemy w synodzie Łubieńskiego z 1641 r. polecenie skierowane do oficjałów i innych sędziów kościelnych, aby w załatwianiu i rozstrzyganiu spraw kierowali się odpowiednimi normami prawa diecezjalnego, jak również statutami prowincjalnymi dawnymi i nowymi, świętymi kanonami oraz powszechnym zdaniem doktorów. W związku z tym prawodawca synodalny nakazywał, aby w kancelariach konsystorzy przechowywać statuty tego synodu, a także statuty poprzednich synodów diecezjalnych oraz statuty synodów prowincjalnych. Oficjałowie i notariusze konsystorscy winni przyswajać sobie dobrze zawarte w tych zbiorach normy, stosując się do nich w ferowaniu wyroków. Synod polecił, aby w przyjmowaniu lub odrzucaniu skarg kierować się ściśle przepisami bulli Sacrosancta papieża Leona X wydanej dla Polski 5 sierpnia 1515 r., a co do czasu trwania procesów, stosować się do norm ustalonych przez Sobór Trydencki ${ }^{133}$.

\section{Zakończenie}

Wielki i potrzebny dar reformy i odnowy duszpasterskiej ofiarowany Kościołowi połowy XVI wieku w uchwałach Soboru Trydenckiego, realizowany i wprowadzany w życie Kościołów partykularnych przez kolejne wieki, został gorliwie i owocnie podjęty przez biskupa

\footnotetext{
${ }^{132}$ Acta seu Decreta et Statuta synodalia Wladislaviensis Dioecesis MDCXXXIV, die XVI Maii, et sequentibus sancita, Z. Chodý́ski, Statuta synodalia,..., dz. cyt., s. 212; Synodus Dioecesana sub [...] Mathia Łubieński [...] episcopo Wladislaviensi et Pomeraniae, Wladislaviae, Anno Domini Millesimo Sexcentesimo Quadragesimo Primo, Die Nona Mensis Junii, celebranta, Tamże, s. 233.

${ }^{133}$ Conc. Trid., sess. XXV, c.10 de ref. oraz sess. XXIV , c. 20 de ref.; Synodus Dioecesana sub [...] Mathia Łubieński [...] episcopo Wladislaviensi et Pomeraniae, Wladislaviae, Anno Domini Millesimo Sexcentesimo Quadragesimo Primo, Die Nona Mensis Junii, celebrata. Z. Chodý́ski, Statuta synodalia..., dz. cyt., s. 232.
} 
Macieja Łubieńskiego i to $\mathrm{z}$ wielkim rozmachem na trzech synodach, dwóch diecezjalnych w 1634 i 1641 r. oraz na synodzie odbytym dla archidiakonatu pomorskiego w 1640 r. Ich uchwały stały się nie tylko okazją do przeprowadzenia odnowy duszpasterskiej Kościoła włocławskiego, ale także przyczyniły się do pogłębienia znajomości i szacunku dla prawa oraz stały się skutecznym instrumentem do zachowania jedności i karności kościelnej w diecezji, jak też wprowadzania reformy trydenckiej. Osadzone mocno w dekretach soborowych oraz statutach prowincjonalnych uchwały synodów normowały wiele sektorów życia duszpasterskiego ówczesnej diecezji kujawsko-pomorskiej, uaktywniając samych duszpasterzy, jak i angażując religijnie i moralnie wiernych świeckich. Ten wybitny ustawodawca, reformator i zwolennik odnowy trydenckiej Kościoła i jego struktur duszpasterskich, zdawał sobie sprawę, że odnowa duszpasterstwa i naprawa życia religijno-moralnego musi znaleźć swój początek w reformie duchowieństwa, zachowaniu karności i dyscypliny kościelnej oraz w życiu i postępowaniu duchownych zgodnym z duchem powołania kapłańskiego. Uchwały synodalne biskupa Łubieńskiego były przejawem jego gorliwości ustawodawczo - reformistycznej. Usilnie zabiegał o ujednolicenie przepisów prawnych odnoszących się do życia sakramentalnego, dyscypliny duchowieństwa oraz rozwoju życia religijnego, a jednocześnie rozwoju duszpasterstwa. Jego działalność ustawodawcza i prawno-duszpasterska była w miarę usystematyzowana, szeroka i całościowa. Odnosiła się bowiem najpierw do działalności czysto ustawodawczej, a także miała charakter praktyczny, gdyż odnosiła się i służyła odnowie duszpasterstwa i życia religijnego wiernych.

Odnowie duszpasterstwa służyły też podejmowane wysiłki zmierzające do usprawnienia organizacji dekanatów oraz ożywienie działalności dziekanów, m.in. w zakresie kontroli duszpasterstwa, przypominania proboszczom ich powinności w zakresie poznawania parafian, opieki nad chorymi i ubogimi, zarządzenia odnoszące się do obrony wiary katolickiej zagrożonej reformacją, regulacje odnoszące się do nauczania prawd wiary, nauczania katechetycznego, sprawowania i przyjmowania sakramentów, kultu Bożego i spraw 
liturgicznych. To wszystko miało służyć posoborowej odnowie duszpasterstwa w Kościele włocławskim.

\section{Renewal of pastoral-religiosus in the diocese of Włockawek in the light of resolutions Synods Bishop Maciej Łubieński (1631-1641)}

Dar reform and renewal of pastoral offered to the Church the mid-sixteenth century in the resolutions of the Council of Trent, implemented and put into practice the particular Churches by successive centuries been zealously and fruitfully undertaken by Bishop Matthias Łubieński and with great gusto on three synods, two diocesan in 1634 and 1641 and at the Synod for archdeaconry of Pomerania in 1640. Their resolutions have become not only an opportunity to carry out pastoral renewal of the Church of Wloclawek, but also helped to deepen knowledge of and respect for the law and become an effective instrument to preserve the unity and discipline of the Church in the diocese, as well as the introduction of the Tridentine reform. Placed firmly in the conciliar decrees and resolutions of provincial synods statutes governed the many sectors of pastoral life of the diocese then Kuyavian-Pomeranian activating pastors, and engaging religiously and morally lay faithful. This outstanding legislator, reformer and supporter of the renewal of the Tridentine Church and its pastoral structures, he realized that the renewal of pastoral care and repair of life of religious and moral needs to find its origin in the reform of the clergy, maintaining discipline and discipline of the Church and in the life and behavior of the clergy in line with the spirit the priestly vocation. Resolutions of the Synod of Bishop Łubieński were a manifestation of his zeal legislative, - a reformist. Strongly urged by the harmonization of laws relating to the sacramental life, the discipline of the clergy and the development of religious life, while the development of pastoral care. His legislative activity, legal and pastoral was as structured, broad and comprehensive. She referred first to the fact purely legislative activity, and also had a practical nature, as refer to and serve the renewal of pastoral care and religious life of the faithful.

Pastoral renewal efforts also served to reinforce the organization deaneries and the revival of activity deans, among others, in the control of pastoral remind parish priests of their duties in the field of studying parishioners, 
care for the sick and the poor, regulations relating to the defense of the Catholic faith threatened the Reformation, the regulations relating to teach the truths of the faith, teaching catechetical exercise and the sacraments, worship of God, and affairs liturgical celebrations. It all had to serve the post-conciliar renewal of pastoral ministry in the Church Wloclawek.

SŁowA KLUCzowE: biskup Maciej Łubieński; synody diecezji włocławskiej; reforma trydencka; ustawodawstwo diecezjalne; Sobór Trydencki; diecezja włocławska

KeY wORDs: Bishop Maciej Łubieński; synods diocese Włocławek; the Tridentine reform; legislation diocesan; Council of Trent; the diocese of Włocławek

\section{Nota o Autorze:}

Ks. DR HAB. JANUSZ GRĘźLIKowSKi, PROF. UKSW - profesor nadzwyczajny na Wydziale Prawa Kanonicznego UKSW w Warszawie, kierownik Zakładu Historii Prawa Kanonicznego, Oficjał Sądu Biskupiego diecezji włocławskiej. 